\title{
Historiografia Econômica do Dízimo Agrário na Ibero-América: Os Casos do Brasil e Nova Espanha, Século XVIII
}

\author{
Angelo Alves Carrara \\ Professor - Departamento de História - Universidade Federal de Juiz de Fora (UFJF) \\ Endereço para contato: José Lourenço Kelmer, s/n - Campus Universitário - Juiz de Fora - MG \\ CEP: 36036-330 - E-mail: angelo.carrara@ufjf.edu.br
}

\section{Ernest Sánchez Santiró}

Instituto de Investigaciones Dr. José María Luis Mora/México Instituto Mora. Plaza Valentín Gómez Farías, 12, col. San Juan Mixcoac

Del. Benito Juárez, México, DF - E-mail: esanchez@mora.edu.mx

Recebido em 10 de março de 2012. Aceito em 17 de agosto de 2012.

\section{Resumo}

O propósito deste artigo é duplo. De um lado, apresentar uma visão global sobre a evolução historiográfica do dízimo na Nova Espanha e no Brasil, incidindo especialmente nos aspectos econômicos. Por outro lado, apontar em que medida os dados decimais do século XVIII em ambos os espaços permitem responder a questões relativas ao fenômeno do crescimento da produção agrícola em uma e outra região.

\section{Palavras-Chave}

dízimos, Brasil, México

\begin{abstract}
This article aims at presenting an overview of the historiographical evolution concerning the tithes in New Spain and Brazil, focusing especially on the economic features. On the one hand, it intends to point out in what measure the eighteenth century tithal records allow us to answer, in both regions, some issues relating to the economic growth of the agricultural production in one and another space.
\end{abstract}

\section{Keywords}

tithes, Brazil, Mexico

JEL Classification

N01, N26 


\section{Introdução}

O propósito deste texto é duplo. De um lado, apresentar uma visão global sobre a historiografia do dízimo na Nova Espanha e Brasil, incidindo especialmente em seus aspectos econômicos, e, de outro lado, e com maior ênfase, assinalar em que medida os dados decimais do século XVIII em ambas as latitudes permitem apontar para um fenômeno de crescimento da produção agrícola nos dois territórios. O estudo está integralmente baseado na historiografia sobre o tema em ambos os espaços. Como poderá observar o leitor, há um evidente desequilíbrio entre a parte reservada ao estudo do dízimo no México e no Brasil, motivado em grande medida pelo diferente desenvolvimento deste tópico nos dois países. ${ }^{1}$

Como ponto prévio cabe destacar que existem dois elementos que diferenciam em termos institucionais o dízimo em cada um destes espaços. $\mathrm{O}$ primeiro deles faz referência à autoridade que detinha o direito para arrecadá-lo e administrá-lo na América. No caso dos territórios americanos da monarquia católica, a Coroa espanhola recebeu os dízimos do papa Alexandre VI mediante a bula Eximiae devotionis, datada de novembro de 1501 , na qual se dizia...

"[...] pelas presentes como graça especial, com autoridade apostólica, concedemos a vós e a vossos sucessores que podeis perceber e levar livremente os ditos dízimos em todas as ilhas e províncias [das Índias] de todos os seus vizinhos....".

Uma "doação" que tinha uma lógica plenamente econômica (além de política, claro está) na medida em que a implantação da Igreja nas Índias não se podia fazer sem o concurso dos monarcas espanhóis. Em troca de que a Coroa fundasse e dotasse os novos estabelecimentos eclesiásticos, o papado outorgava-lhe os rendimentos futuros dos dízimos que, em princípio, caberia à Igreja arrecadar e administrar. ${ }^{3}$

1 Se fizermos uma primeira comparação quantitativa, é evidente o desequilíbrio: 64 trabalhos cobrem o caso do México e 13 o do Brasil.

2 Medina (1983), p. 51.

3 Heras (1992), pp. 515-516.

Est. Econ., São Paulo, vol. 43, n.1, p.167-202, jan.-mar. 2013 
A esta medida sucedeu a denominada concórdia de Burgos de 1512, na qual Fernando II, o Católico, concedeu a renda decimal aos primeiros bispos das Américas, prelados que iam se assentar no espaço antilhano recentemente descoberto e ocupado. ${ }^{4}$

Mas ainda que este tenha sido o marco jurídico que determinou a autoridade encarregada de coletar e administrar o dízimo nas Índias espanholas, a casuística será a nota que marcou as circunstâncias de sua aplicação em cada um dos territórios que se foram anexando à monarquia. Assim, com a conquista de México-Tenochtitlán em 1521 incorporou-se um imenso território continental no qual produzirse-ia uma disputa pelo controle da renda decimal.

Com clara orientação regalista, Carlos I e seus ministros atuaram na Nova Espanha segundo os princípios estabelecidos nas bulas papais que lhes outorgavam originariamente os dízimos, como se pode observar nas numerosas ordens régias dos anos 1539-1540, de forma que o dízimo foi coletado e administrado pela Coroa. No entanto, à medida que a Igreja diocesana novo-hispana era implantada e se fortalecia, foi adquirindo maior controle sobre a renda dos dízimos. De fato, entre 1568 e 1585, anos em que se celebraram o segundo e terceiro Concílio Mexicano, produziu-se uma progressiva transferência dos dízimos e sua administração dos ministros da Coroa às autoridades eclesiásticas. ${ }^{5}$ Como manifestação fiscal da titularidade última da renda decimal, as Igrejas diocesanas teriam de entregar à Real Fazenda os "dois nonos" da renda decimal (isto é, 11,1\% do dízimo líquido partível). Daí que os dízimos novo-hispanos fossem "eclesiásticos". ${ }^{\circ}$

A Coroa portuguesa também recebeu como doação a faculdade de coletar e administrar o dízimo no Brasil. Em 1456 o papa Calixto III outorgou à Ordem de Cristo, da qual o monarca português era grão mestre, a autoridade eclesiástica em todas as terras desde os cabos Bojador e não "sem interrupção até as Índias".

\footnotetext{
Heras (1992), p. 523.

Medina (1983), pp. 90-91.

Schwaller (1990).

Segundo o texto em latim: "a capitibus de Bojador et de Nam usque per totam Guineam et ultra illam meridionalem plagam usque ad Indos." Bula Inter caetera, de 13 de março de 1456. Transcrita em Davenport, Frances Gardiner. European treaties bearing on the history of the United States and its dependencies. Washington: Carnegie Institution, 1917, p. 29. O cabo Não é conhecido hoje por Chaunar.
} 
A concessão foi incorporada em 1516 às ordenações da Fazenda Real do rei D. Manuel I (capítulo 206), e confirmada em 1550 por um breve do papa Júlio III. ${ }^{8}$

Contudo, o contraste adveio da evolução dessa faculdade. Enquanto que nas Índias espanholas, num lento, porém contínuo processo, a renda decimal acabou sendo arrecadada e administrada pelas autoridades eclesiásticas, chegando a constituir-se na coluna vertebral do fiscus ecclesiasticus, no caso brasileiro a Coroa nunca deixou de exercer o controle direto sobre os dízimos. De fato, como veremos, os dízimos constituíram um dos pilares fiscais básicos da Coroa portuguesa no Brasil durante os séculos XVI e XVII, ${ }^{9}$ perdendo só importância relativa com o desenvolvimento da produção aurífera de Minas Gerais no século XVIII (os quintos) e os impostos aduaneiros (dízima da alfândega). A contrapartida desta situação foi que a "folha eclesiástica" acabou tornando-se parte integrante das despesas da Real Fazenda no Brasil; em algumas ocasiões, com montantes semelhantes aos da folha civil e militar. ${ }^{10}$ Algo que não sucedia no caso novo-hispano, com exceção das terras de recente colonização nas quais a Coroa assumia o sustento dos clérigos. Esta caracterização permite afirmar que os dízimos no Brasil foram uma renda real e não uma renda eclesiástica.

O segundo ponto que diferencia os dízimos em ambos os espaços remete ao sistema de arrecadação empregado. No caso da Nova Espanha, e ao longo dos séculos XVI e XVII, alternaram-se a administração direta dos dízimos por parte da Igreja com o sistema de arrendamento a particulares, os quais entregavam aos cabidos um montante fixo em moeda e/ou gêneros por um período concreto de anos. Em troca, os arrendatários encarregavam-se de arrecadar o dízimo nos distintos espaços fiscais. Seu benefício se dava por vários mecanismos. $\mathrm{O}$ mais claro era a obtenção do contrato de arrendamento dos dízimos por um valor inferior ao das receitas estimadas, mas também por sua função de responsáveis por armazenar os produtos agropecuários dizimados, com os quais se podia dispor de uma posição dominante nos mercados regionais de cereais, gado e

8 Coutinho, José Joaquim da Cunha de Azeredo. Cópia da análise da bula do Smo. Padre Júlio III, de 30 de dezembro de 1550, que constitui o padrão dos reis de Portugal, a respeito da união, consolidação, e incorporação dos Mestrados das Ordens Militares de Cristo, São Tiago e de Avis como os Reinos de Portugal. Londres: T. C. Hansard, 1818.

9 Oliveira (1940) e Lyra (1970).

${ }^{10}$ Como exemplo disto, cf. as receitas e despesas da capitania da Bahia (do ano fiscal de agosto 1713 a julho 1714), Carrara (2009b), p. 75. 
derivados da cana-de-açúcar, algo especialmente atrativo em épocas de más colheitas. Porém, durante o século XVIII foi-se generalizando a administração direta, ${ }^{11}$ o que resultou em que as diversas dioceses novo-hispanas exercessem um maior controle sobre seus rendimentos fiscais. O preço pago foi a criação de uma densa rede de coletorias de dízimos, com armazéns e arrecadadores que se financiavam a partir dos rendimentos decimais. De forma contrastante, no caso do Brasil, a Real Fazenda empregou como sistema habitual o arrendamento dos dízimos. Unicamente nos anos em que não havia interessados, ou quando os lances oferecidos eram claramente inferiores ao esperado, é que as autoridades fiscais da Coroa assumiam a arrecadação e administração dos dízimos, mas como uma situação interina até a celebração de outro contrato de arrendamento.

No que respeita aos dízimos do Brasil, deve-se fazer uma distinção fundamental: até o descobrimento do ouro nos anos finais do século XVII, os dízimos correspondiam fundamentalmente à produção dos gêneros agrícolas destinados à exportação (açúcar e tabaco, principalmente). $\mathrm{O}$ arrendamento se concentrava no eixo Bahia-Pernambuco, que representava $80 \%$ da produção exportável brasileira, ao passo que nas áreas mineradoras os gêneros sobre os quais incidia a cobrança eram os destinados ao abastecimento interno: milho, feijão e carnes, especialmente. Esta diferença, por sua vez, transferiu-se à qualidade da documentação disponível. Assim, enquanto o arrendamento dos dízimos nas capitanias litorâneas gerou séries muito descontínuas dos valores dos contratos, em Minas Gerais a documentação permite análises muito mais detalhadas.

Se no início os dízimos eram arrendados pelo valor estimado do conjunto da produção agrícola brasileira, a partir de 1628 o arrendamento ajustou-se à produção agropecuária de cada capitania. O sistema de cobrança e pagamento era simples: uma vez celebrado o contrato dos dízimos, o arrendatário estava obrigado a pagar trimestralmente nas provedorias o valor correspondente até alcançar o montante total contratado. Na Bahia, o contratador devia pagar, do valor estipulado, duas terças partes em dinheiro e uma outra em tecidos para os uniformes da infantaria daquela praça. No Rio de Janeiro, a proporção era de metade em dinheiro e outra metade em tecidos. Mas o "dinheiro" podia ser também açúcar, já que o que os

${ }^{11}$ Isto, como veremos mais adiante, deve ser matizado porque em determinados "dezmatorios" (lugares onde se recolhiam o dízimo) novo-hispanos o processo foi inverso. 
arrendatários recebiam não era propriamente metal sonante, mas mercadorias, isto é, açúcar, gado, tabaco, etc. Em Minas Gerais, por seu turno, a Real Fazenda só recebia o pagamento na moeda usual da capitania: ouro em pó.

Em geral, um problema rondava permanentemente a prática dos contratos: as fraudes nas arrecadações das rendas reais. Não é exagerado afirmar que estas práticas eram inerentes ao sistema de cobrança de tributos. Contudo, o maior dos problemas enfrentados pela Real Fazenda, e não só em relação aos dízimos, foi a isenção fiscal pretendida pelas ordens religiosas. Os jesuítas já eram litigantes tradicionais, e em 1676 também requereram isenção os religiosos do Carmo da cidade da Bahia, alegando ser mendicantes. Estes problemas foram enfrentados pela Real Fazenda até o século XVIII. ${ }^{12}$

A tendência díspar entre o sistema de arrecadação dos dízimos na Nova Espanha e no Brasil faz com que a qualidade da informação sobre a atividade agropecuária submetida ao imposto decimal seja muito diferente em ambos os espaços; especialmente no século XVIII. Assim, no caso novo-hispano, ainda que com lacunas geográficas e temporais, é possível reconstruir o produto agrário dizimado de diversas dioceses (cargas de milho, trigo e cevada; cabeças de gado maior e menor; açúcar e mel, como os gêneros mais importantes em termos de arrecadação), os titulares ou arrendatários da unidade agrária declarante (fazenda, rancho, sítio, povoado, missão, irmandade, etc.), ou os preços pelos quais se venderam (tanto na unidade produtiva quanto nos mercados finais) a produção dizimada. De igual modo, a riqueza da fonte permite avançar em estudos de caráter fiscal nos quais se constata o rendimento bruto, os custos de arrecadação, os custos derivados dos fretes e armazenamento, assim como o rendimento líquido que, uma vez monetizado, convertia-se no que na época se denominava "dízimo líquido partível". Contudo, no caso brasileiro, a primazia do sistema de arrendamento fazia com que na maioria dos casos estas informações estivessem ausentes. O que se obtém é um valor de dízimo em moeda, resultado de um contrato de arrendamento no qual é muito difícil decifrar em que medida a evolução dos contratos segue a evolução da produção e dos preços. Por sua vez, o sistema brasileiro abre uma porta de análise muito promissora aos estudos de caráter fiscal nos quais se enfatiza a informação desigual e a força dos diversos atores que participavam

12 Carrara (2009b), pp. 45-49. 
dos contratos de arrendamento. Algo que no caso novo-hispano se pode apreciar graças às "igualas" que a Real Fazenda estabelecia com diversos atores econômicos para certos impostos (como no caso das "alcabalas").

\section{O Caso Novo-Hispano}

\subsection{Reconstrução do produto agrário da Nova Espanha durante o século XVIII a partir da fonte decimal: historiografia e princi- pais resultados}

A historiografia sobre o dízimo eclesiástico na Nova Espanha tem uma longa e rica tradição. Já na década de 1940, Woodrow Borah indicou a relevância da fonte decimal para várias temáticas (vida institucional da Igreja, a inserção da economia indígena nos nascentes circuitos mercantis, o peso da contribuição indígena na fiscalidade eclesiástica, a submissão da Igreja às diretrizes da Coroa em matéria de dízimos, a partir das doações papais, etc.). ${ }^{13}$ Não obstante, estes primeiros esforços não levaram ao desenvolvimento de trabalhos que localizassem, reconstruíssem e explicassem o comportamento da renda decimal nos diversos bispados novo-hispanos. Neste sentido, o trabalho de Michael Costeloe de 1966, que reconstruiu os aspectos gerais do comportamento dos dízimos do arcebispado do México no período de 1800-1860 (isto é, do esplendor do vice-reino à crise deste imposto no marco do Estado-nação) constitui um fato bastante isolado. ${ }^{14}$

Foi na década de 1970 que os dízimos constituíram-se tópico relevante da historiografia econômica da Nova Espanha. Uma relevância que deixava transparecer o impacto das propostas de construir uma história serial e quantitativa promovidas pela escola dos Annales e a Nova História Econômica. O volume, riqueza, ubiquidade e ampla temporalidade da fonte decimal convertiam-na num recurso ideal para o estudo do desempenho da produção agropecuária novo-hispana. Assim, em uma rápida sequência, apareceram diversas obras que,

13 Borah (1941) e (1949).

14 Costeloe (1966). A temática dos dízimos, inserida na reconstrução das difíceis relações entre a Igreja e os primeiros governos do México, reapareceria quase uma década depois na obra de Anne Staples (1976). 
com metodologias diferentes, objetivos diversos e alcances desiguais, propuseram-se o estudo do agro em três bispados fundamentales: Michoacán, Puebla e Oaxaca. ${ }^{15}$

Apesar de que alguns destes estudos reconstruíram os traços básicos da produção agrícola, assim como sua dinâmica, em localidades emblemáticas para o processo independentista (Dolores Hidalgo, San Miguel el Grande), cabe destacar o impacto historiográfico das obras de Aristides Medina sobre a produção agrícola do bispado de Puebla entre os séculos XVI e XVIII, ${ }^{16}$ de Claude Morin, sobre o movimento da produção agrícola no bispado de Michoacán ${ }^{17}$ e de David Brading sobre a evolução das fazendas e os ranchos de uma das principais zonas do Bajío novo-hispano: León, na intendência/estado de Guanajuato. Um espaço relevante como o Bajío havia-se constituído historiograficamente no emblema do crescimento econômico do século XVIII, mas também da crise da economia mexicana em suas primeiras décadas de vida independente. ${ }^{18}$ Não obstante, trabalho metodologicamente mais cuidadoso, na medida em que integrou uma pluralidade de variáveis significativas para a explicação do comportamento do agro novo-hispano (população, dízimo em gêneros, dízimo líquido, índices de preços, unidades e tipologia dos declarantes, etc.), foi o realizado por Cecilia Rabell para um "dezmatorio" setentrional do bispado de Michoacán: San Luis de la Paz. ${ }^{19}$ Pela primeira vez, dispunha-se na historiografia econômica sobre o agro novo-hispano de uma reconstrução dos valores nominais e deflacionados da produção agropecuária de um "dezmatorio", além do que o período abarcado cobria quase em sua totalidade o século XVIII longo (1673-1804).

\footnotetext{
${ }^{15}$ Hurtado (1974), Medina (1974), Galicia (1975) e (1978), Rabell (1975), Brading (1978), Morin (1979), Pastor et al. (1979), Flores Garcia (1980). Alguns destes trabalhos, como o Rodolfo Pastor et al. (1979) sobre os dízimos do bispado de Oaxaca receberam resenhas críticas em virtude de que grande parte das conclusões estabelecidas no trabalho se realizavam a partir do emprego do dízimo em moeda, sem contemplar (por problemas da fonte) índices de preços que o deflacionassem. A este respeito, cf. Lindo Fuentes (1980). Para obras que nesta mesma década empregaram registros de dízimos, especialmente as variações nos preços de produtos básicos como o milho e o feijão no contexto da crise da ordem colonial (1800 e 1815), ainda que sem fazer dos dízimos a fonte fundamental de sua investigação, cf: Hamnett (1971). Igualmente por esses anos se realizaram trabalhos no Departamento de Investigações Histórica do INAH, muitos dos quais inéditos, que exploravam as possibilidades da fonte decimal (uma geografia econômica da produção agropecuária, as práticas monopólicas sobre certos produtos básicos, a composição social dos declarantes ou o comportamento econômico das unidades produtivas indígenas). A este respeito, cf.: Florescano e Espinosa, vol. I (1982), pp. 12-13.

16 Media (1983).

17 Morín (1979).

18 Brading (1978).

19 Rabell (1975) e (1985).
}

Est. Econ., São Paulo, vol. 43, n.1, p.167-202, jan.-mar. 2013 
Paralelamente a estes trabalhos apareceram os primeiros resultados das investigações realizadas por John J. TePaske e Herbert S. Klein sobre as "cartas-cuentas" da Real Fazenda nos diversos espaços americanos inscritos na monarquia católica. Como elemento chave desta tarefa foi a publicação, coordenada por John J. TePaske, das "cartascuentas" da Caja (Tesouraria da Real Fazenda) do México para o período $1576-1816 .{ }^{20} \mathrm{O}$ interesse dos dados publicados radicava em que ali se podiam encontrar os "novenos reales" (os assim chamados "dos novenos") que a Coroa recebeu a partir dos dízimos arrecadados pela diocese metropolitana da Nova Espanha. Com isto se podia aventurar na reconstrução da curva do dízimo líquido do arcebispado do México, o grande ausente na historiografia sobre a renda decimal na década de $1970 .^{21}$

Esta linha de investigação que fazia dos dízimos a fonte mais adequada para a análise da produção agropecuária em áreas extensas do vice-reino, recebeu um decidido impulso com a publicação de um corpus documental massivo pertencente ao bispado de Michoacán, que recolhia de maneira sistemática e para uma cronologia extensa (1636-1810) as quantidades declaradas sob a rubrica de dízimo de uma grande variedade de produtos (gado maior e menor, cereais, leguminosas, açúcar, mais os respectivos derivados, etc.), seus preços, assim como o valor final da produção declarada. Trata-se da obra coletiva coordenada por Enrique Florescano e Lydia Espinosa intitulada Fuentes para el estudio de la agricultura colonial en la diócesis de Michoacán: series de diezmos 1636-1810.22

Com esta bagagem, a historiografia econômica sobre a agricultura novo-hispana da década de 1980 passou a incorporar os métodos e resultados dos estudos sobre a renda decimal, especialmente durante o século XVIII, ao dispor de uma fonte que, submetida a um cuidadoso tratamento, constituía-se em poderoso indicador de seu desempenho econômico. ${ }^{23}$ Exemplos destacados desta orientação acham-se

${ }^{20}$ TePaske (1976).

${ }^{21}$ Os "dois nonos" representavam 11,1\% dos dízimos líquidos partíveis, depois de descontar os custos de arrecadação, transporte, armazenamento e venda (fosse nas coletorias de dízimos, fosse na cidade do México). Fonseca e Urrutia, vol. III (1850), pp. 260-262 e "Estado segundo".

22 Florescano e Espinosa (1987-1989).

${ }^{23}$ Deve-se destacar que, de maneira paralela a esta historiografia, foi-se desenvolvendo um conjunto de trabalhos que tinham como núcleo de estudo as dioceses novo-hispanas, tanto em sua conformação histórica como em suas relações com a autoridade monárquica. Autoridades que exerceriam uma dura pugna pelo controle dos dízimos durante os séculos XVII e XVIII. Farriss (1968), Mazín (1987) e (1996), Brading (1994), Jaramillo (1996), Pérez Puente (2001) e (2005). 
no trabalho de Juan Carlos Garavaglia e Juan Carlos Grosso para a região de Puebla-Tlaxcala entre 1680 e $1800,{ }^{24}$ e o que realizou Rodolfo Pastor para a região de Mixteca, no bispado de Oaxaca, entre $1700-1856 .^{25}$

Neste contexto apareceu uma crítica que colocava sob suspeita o uso do dízimo, concretamente do "dízimo líquido", 26 como um indicador fiável do desempenho do agro novo-hispano a partir da conhecida constatação de que tal dízimo era o resultado não só da relação entre produção e preços, mas igualmente do impacto provocado pelas reformas administrativas empreendidas pelos diversos cabidos para aumentar a arrecadação, fosse através do aumento da base fiscal, fosse mediante a redução dos custos de arrecadação. ${ }^{27}$

O título do trabalho de Ouweneel e Bijleveld não podia ser mais expressivo: "The economic cycle in Bourbon Central Mexico: a critique of the recaudación del diezmo liquido en pesos". Contudo, esse trabalho não apenas questionava o uso do dízimo líquido em pesos como indicador do desempenho da agricultura novo-hispana, especialmente quando diversos trabalhos assinalavam a existência de um processo inflacionário bastante marcado na Nova Espanha a partir da década de 1780, mas também buscou determinar através de diversos procedimentos estatísticos o peso do que os autores denominaram "variáveis inflacionárias, burocráticas e de poder aquisitivo" na evolução dos dízimos das duas dioceses mais estudadas até esse momento: Michoacán e Puebla.

Aqui é onde esta proposta recebeu uma resposta contundente por parte de diversos historiadores (David Brading, John Coatsworth, Héctor Lindo Fuentes), que consideraram que os cálculos não vinham acompanhados de um suporte teórico que lhes conferisse solidez, ao passo que alguns dados empregados careciam de uma crítica

${ }^{24}$ De fato, a comparação entre os dízimos expressos em pesos da diocese de Puebla com os de Michoacán levou os autores a constatar a estagnação e pobre desempenho do agro poblano diante do muito mais dinâmico e positivo da produção agropecuária michoacana. Garavaglia e Grosso (1986).

${ }^{25}$ Um trabalho que teve a particularidade de prologar a análise da renda decimal ao período independente, com emprego detalhado dos dados sociais (v.g. composição étnica) dos contribuintes, como manifestação de algumas das mudanças vividas por agro oaxaquenho no momento da independência. Pastor (1987).

26 Por dízimo líquido deve-se entender o dízimo monetizado ao qual se descontaram os gastos de arrecadação.

${ }^{27}$ Uma advertência que de forma mais ou menos explícita, já haviam feito anteriormente os mesmos autores que agora eram questionados neste trabalho. Ouweneel e Bijleveld (1989). 
consistente de fontes (caso das "cartas cuentas" da Real Fazenda) ou não eram unívocos em seu significado (por exemplo, os protestos camponeses ou a construção de edifícios monumentais). ${ }^{28}$

Uma das arestas da polêmica em torno do uso do dízimo líquido tinha sido o problema da inflação. Como destacamos, sem curvas de preços para deflacionar o valor da produção agropecuária não se poderia saber se os dados indicavam um crescimento do produto agrário real ou nominal. É sintomático que, a partir de então, os trabalhos que pretenderam analisar a produção agropecuária tenham primado pela reconstrução do dízimo em gênero e, quando possível, seu valor econômico a partir da reconstrução dos preços agrários. ${ }^{29}$ Isto consistia numa problemática que se tornou especialmente relevante para o comportamento dos preços agrícolas do período 1780-1810, na medida em que tudo parecia apontar para o fato de que ocorrera um forte processo inflacionário no conjunto do vice-reino. ${ }^{30} \mathrm{~A}$ partir da década de 1990, a produção historiográfica sobre a agricultura novo-hispana reconstruída com a fonte decimal experimentou uma evolução até certo ponto paradoxal. Se de um lado a produção agropecuária continuou sendo um dos temas de estudo, ${ }^{31}$ uma vez mais com o século XVIII como o período mais atendido, ${ }^{32}$ o tópico foi perdendo um perfil próprio, passando a ser um componente a mais no tratamento de outras problemáticas socioeconômicas, como o uso dos rendimentos decimais como mecanismo de crédito agrícola, a formação dos mercados rurais ou as contradições sociais que, geradas pelo crescimento econômico, derivaram numa intensificação da luta pelo controle da terra. ${ }^{33}$

${ }^{28}$ Estas críticas apareceram no mesmo número da revista Hispanic American Historical Review, Vol. 69, No. 3 (Agosto, 1989), pp. 531-549.

${ }^{29}$ Para esta preocupação por consignar não só os gêneros, mas a evolução dos preços agrários, ver: Espinosa Morais (1995), Silva Riquer (1997) e Alaniz (2005).

${ }^{30}$ Esta problemática da inflação finissecular foi exposta por Enrique Florescano em 1969 a partir da análise serial e quantitativa dos preços do milho registrados no "pósito" e "alhóndiga" da cidade do México [Florescano (1969)] e disto derivou um longo debate que, para além do acordo sobre os movimentos de alta nos preços temporal e regionalmente consignados, não está ainda fechado. Frente a autores que propõem a existência deste fenômeno [cf.: Garner (1985) e (1992), Reher (1992), Garcia Acosta (1995), Garner e Garcia Acosta (1995)] contamos com posições muito críticas com relação a tal processo: Romano (1998).

31 Os trabalhos de Jorge Silva Riquer sobre o agro de determinados "dezmatorios" de Michoacán [Silva Riquer (1995) e (1997)] ou os de Ernest Sánchez Santiró sobre a produção açucareira dos vales de Cuernavaca e Cuautla [Sánchez Santiró (2001)], assim o testemunham.

32 De fato, a reconstrução da arrecadação decimal de períodos anteriores (séculos XVI e XVII) constitui uma rara exceção motivada em grande medida pela carência de fontes e pelo predomínio do sistema do arrendamento como sistema de arrecadação. Como exemplos destes trabalhos sobre os períodos anteriores, cf.: Schwaller (1985) e Romero Alaniz (1999).

33 Sánchez Maldonado (1994), Quintanar Zárate (2007) e Durán Sandoval (2007). 
Ainda que esta revisão tenha privilegiado os trabalhos centrados no desempenho econômico agrário novo-hispano a partir da renda decimal, cabe destacar que nos últimos anos cresceu o interesse pelo uso desta fonte para analisar tanto as mudanças ocorridas na agricultura no período compreendido entre a guerra de independência e as primeiras décadas do México como país independente, em particular com a abolição da coação civil do dízimo que se produziu até 1833, momento no qual o dízimo passou de imposto a donativo.

Neste sentido, mesmo que alguns autores tenham considerado os dados de arrecadação do dízimo do período 1810-1821 como indicadores de queda da produção, ${ }^{34}$ parece claro que a partir de 1810 a fonte decimal deixa de ser uma referência para constatar o desempenho da agricultura em termos de produto agrícola (mas não em temas como a titularidade das propriedades, as unidades em operação, os processos de subdivisão e arrendamento das unidades produtivas ou a geografia histórica da produção, para citar alguns tópicos relevantes, para os quais continua sendo de grande utilidade) já que a resistência e a evasão fiscal adquiriram níveis muito elevados. ${ }^{35}$ De fonte para o estudo da agricultura, converte-se numa fonte primordial para o estudo da crise do fisco eclesiástico e das relações conflituosas entre a Igreja e o Estado-nação.

\subsection{Algumas estimativas sobre o produto agrário novo-hispano no século XVIII}

Antes de apresentar as estimativas sobre a produção agropecuária novo-hispana no século XVIII, é conveniente registrar sobre o que incidia este imposto, quem eram os contribuintes e como se realizava o pagamento. E aqui as particularidades de cada diocese e, inclusive, de cada "dezmatorio" (distritos fiscais para arrecadação do imposto) são a nota geral que reflete um mundo jurídico construído a partir de casos e situações específicas.

\footnotetext{
34 Para o caso das regiões centrais do bispado de Puebla, cf.: Cervantes (1999). No caso da região produtora de prata no arcebispado do México, ver: Menegus (2000).

35 Bravo e Pérez (2001), Corvera (2004), Sánchez Santiró (2008), Aguirre (2009). Sem dúvida, o trabalho de Carlos Alberto Ortega é o que mais deixou claro o impacto da resistência fiscal e a evasão a partir de uma análise que integrou os avanços da sociologia fiscal. Ortega (2010). Observe-se que não existem muitos trabalhos que enfrentem o estudo dos dízimos depois da abolição da coação civil do dízimo em 1833. Para este tema consultar: Pérez Mendoza (2003) e Ortega (2010).
} 
Em princípio, o dízimo eclesiástico ${ }^{36}$ gravava $10 \%$ da produção agrária bruta na Nova Espanha, mas a situação era um pouco mais complexa, como podemos verificar no caso do arcebispado do México (ver Tabela 1). ${ }^{37}$

Tabela 1. Principais produtos dizimados com sua respectiva quota tributária Arcebispado do México (1810-1833)

\begin{tabular}{|c|c|}
\hline Produtos agrícolas & Produtos pecuários \\
\hline sésamo $10 \%$ & aves $10 \%$ \\
\hline ervilhaca $10 \%$ & bezerros $10 \%$ \\
\hline algodão 10\% & burros $10 \%$ \\
\hline anil $10 \%$ & cordeiros $10 \%$ \\
\hline arroz 10\% & cabritos $10 \%$ \\
\hline café $10 \%$ & leitões $10 \%$ \\
\hline abóbora $10 \%$ & mulas $10 \%$ \\
\hline cevada $10 \%$ & mulinhas $10 \%$ \\
\hline pimenta $10 \%$ & potros $10 \%$ \\
\hline feijão 10\% & vacas $10 \%$ \\
\hline fruta $^{*} 10 \%$ & derivados \\
\hline grão de bico $10 \%$ & açúcar 4\% \\
\hline fava $10 \%$ & lã $10 \%$ \\
\hline hortaliças $10 \%$ & leite $5 \%$ \\
\hline lentilha $10 \%$ & mel $6 \%$ \\
\hline milho $10 \%$ & "panocha" 6\% \\
\hline batata $10 \%$ & pulque $4 \%$ \\
\hline trigo $10 \%$ & queijo $5 \%$ \\
\hline grama $10 \%$ & lãs 10\% \\
\hline
\end{tabular}

* laranja, melão, limão, banana, tuna, sandía, granada.

Fonte. Ortega (2010), p. 62.

Apesar de a maioria dos produtos agrícolas e pecuários pagarem esta taxa, sobre alguns derivados seus recaía uma carga menor, como no caso dos $5 \%$ para o queijo, dos $6 \%$ para o mel, e os $5 \%$ para leite. Isto é especialmente relevante no caso de dois produtos com alta demanda entre a população novo-hispana: o pulque (4\%), uma bebida fermentada de origem pré-hispânica muito difundida entre a população indígena e de castas, e a panocha (6\%), um derivado da cana-

\footnotetext{
${ }^{36}$ A adjetivação é necessária já que existia também o dízimo mineiro, isto é, $10 \%$ da produção de ouro e prata, que os mineradores pagavam à Coroa como manifestação fiscal de suas regalias, neste caso, o domínio eminente sobre o subsolo.

37 Isto é, era um imposto direto que tinha como fato gerador as atividades agrícola e pastoril. Uma vez estabelecida a base impositiva, a produção agropecuária se lhe aplicava a quota tributária: 10\% da produção. Ortega (2010).
} 
de-açúcar, que constituía um adoçante muito comum na gastronomia novo-hispana de todos os grupos sociais. Mais relevância em termos econômicos, tanto pelos volumes de produção como pelo alto preço relativo no mercado, tinha o açúcar (em suas diferentes variedades: branca, demerara e mascavo), que pagava $4 \%$.

Em relação aos contribuintes, desde o século XVI se pretendeu instaurar na Nova Espanha uma sociedade segmentada na qual, por um lado, a população peninsular e a derivada do processo de mestiçagem devia se articular em torno das repúblicas de espanhóis, ao passo que a população indígena devia fazê-lo nas repúblicas de índios. O resultado fiscal desta divisão foi a adscrição dos impostos segundo a qualidade ou casta dos indivíduos. Assim, os espanhóis, castiços e mestiços não pagavam o tributo, os índios estavam isentos do pagamento das alcabalas e dos dízimos eclesiásticos, enquanto que a população negra e mulata enfrentava o pagamento de todos os tributos.

Contudo, a isenção de que gozavam os indígenas ficava limitada aos "bens da terra" (milho, feijão, pimenta, cochonilha, algodão, baunilha, perus, etc.), de forma que a produção indígena de trigo, cevada, centeio, uva, cana-de-açúcar (como casos mais relevantes) e de gado maior e menor estava submetida ao imposto. Inclusive se seu cultivo se realizasse nas terras arrendadas a fazendas e ranchos de população não indígena, mesmo que fossem bens da terra, também estavam então obrigados ao pagamento do dízimo. ${ }^{38}$

A desigual obrigação fiscal da população segundo o tipo de produtos e a etnia dos contribuintes, que resultou num "dízimo de espanhóis" e um "dízimo de índios", fez com que amplas porções da produção agropecuária permanecessem à margem do tributo eclesiástico, já que os indígenas eram os que geravam a maior parte da produção agropecuária que constituía a base da alimentação da população, formada pela tríade milho-feijão-pimenta. ${ }^{39}$

${ }^{38}$ Aqui a casuística é interminável, já que em certos "dezmatorios" os indígenas pagavam dízimo sobre alguns produtos da terra, apesar de se produzir nas terras da comunidade, enquanto que em outros gozaram de maiores isenções. Isto era o resultado de um imposto que se foi construindo de forma paulatina entre os séculos XVI e XVIII, determinado pelos diversos privilégios outorgados pelas autoridades no processo de colonização do território e pela pressão exercida pelas autoridades eclesiásticas para incrementar seus rendimentos fiscais.

${ }^{39}$ Isto não quer dizer que os indígenas estivessem à margem da produção e consumo de produtos como o trigo, a cana-de-açúcar ou o gado maior e menor (além de seus derivados e subprodutos), ainda que aqui o peso das fazendas e ranchos de espanhóis e castas foi majoritário. 
Com estas prevenções podemos considerar que o dízimo novo-hispano constitui um bom indicador da produção agropecuária gerada pelas fazendas e ranchos, isto é, a produção destinada aos mercados regionais e, em certas ocasióes, ultramarinos (é o caso do trigo "poblano" destinado ao abastecimento de diversas praças do Caribe), mas um péssimo guia para a produção voltada ao autoconsumo da população camponesa, que era majoritariamente indígena. $\mathrm{O}$ corolário desta situação seria que os registros decimais constituem uma boa aproximação ao comportamento da agricultura mercantil novo -hispana, sabendo que estamos diante de uma economia na qual o componente natural (autoconsumo e troca) ocupava, segundo diversos autores, entre 50 e $70 \%$ nos finais do século XVIII. ${ }^{40}$

Quanto às formas de pagamento, o estipulado pelas normas que regiam a cobrança do dízimo indicava que tinha que ser pago em gêneros, e de fato assim se registrava nas "declarações" dos contribuintes. Porém, uma vez determinado o montante do dízimo, o pagamento podia efetuar-se em dinheiro, considerando-se o preço dos bens no mercado local. No caso de que se pagasse em dinheiro, o desembolso podia ser feito ou em moeda ou mediante a apresentação de uma livrança (ordem de pagamento contra um terceiro). ${ }^{41}$ A Igreja contemplou a possibilidade de que os contribuintes não pudessem realizar o pagamento em um único momento, de forma que considerou os pagamentos atrasados, desde que com a assinatura de diversos instrumentos de crédito (no caso de valores superiores a um determinado nível, normalmente 100 pesos, hipotecas e escrituras; e em valores inferiores, vales). ${ }^{42}$

Finalmente, quanto aos mecanismos de arrecadação, a historiografia registrou que uma tendência nas dioceses novo-hispanas durante o século XVIII foi a progressiva generalização do sistema de administração direta em lugar dos arrendamentos. Mesmo que isto não pareça claro nos casos do arcebispado do México e os bispados de Puebla e Oaxaca, no caso do bispado de Michoacán podem-se considerar três etapas. ${ }^{43}$ Graças ao estudo de Felipe Durán avalia-se que entre as décadas de 1700 e 1720 predominou o sistema de arrenda-

\footnotetext{
${ }^{40}$ Sánchez Santiró (2007), pp. 145-146.

${ }^{41}$ Ortega (2010).

42 Sánchez Maldonado (1994).

43 A falta de estudos sobre os sistemas de arrecadação decimal no conjunto das dioceses novo -hispanas que abarquem a totalidade do século XVIII torna o que se disse aqui uma primeira aproximação. Todavia, cabe destacar que o aqui proposto para o bispado de Michoacán difere do mostrado até agora. Cf. Pastor et al. (1979), p. 20.
} 
mento, momento a partir do qual cresceu a gestão direta por parte do cabido eclesiástico, de maneira que em 1765, 37 "dezmatorios" do bispado arrecadavam o dízimo mediante o sistema de administração direta e 20 através de arrendamentos. Porém, à altura de 1800 a relação era inversa: 11 "dezmatorios" eram administrados e 36 eram arrendados. $^{44}$

Apesar de que esta evolução não implicasse uma diminuição para os rendimentos da Igreja michoacana, concorria de fato para um controle da informação muito diferente. O exemplo do "dezmatorio" de San Luis Potosí, na diocese de Michoacán ilustra esta situação (ver Gráfico 1):

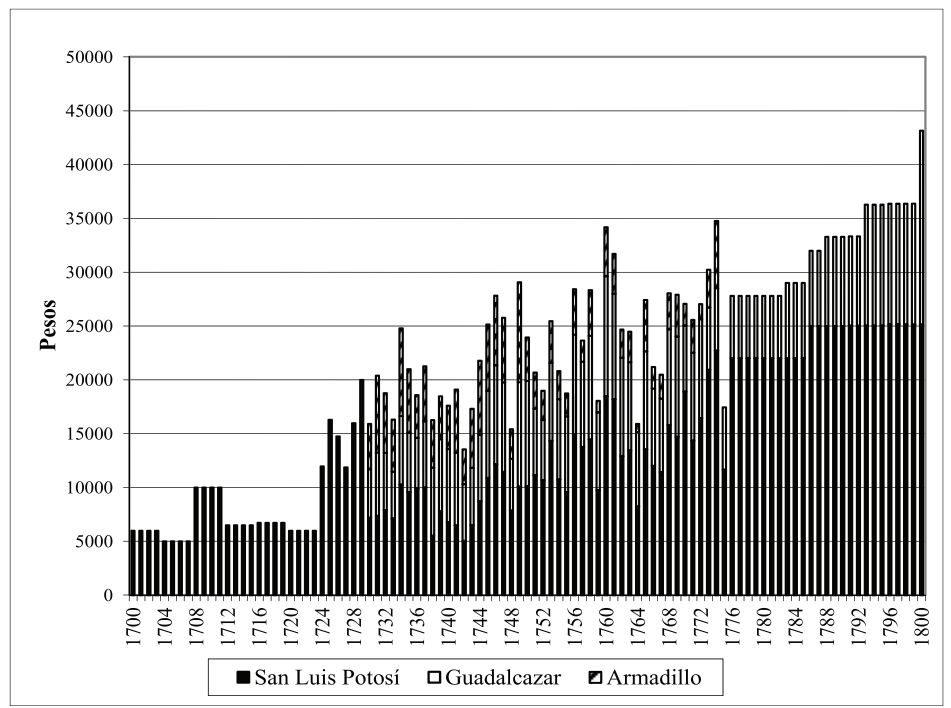

Gráfico 1 - Dízimo bruto do "dezmatorio" de San Luis Potosí (1700-1800)

Fonte: Durán Sandoval (2007).

Podemos verificar como no "dezmatorio" de San Luis Potosí, formado por três "partidos" (isto é, áreas) decimais (o homônimo, o de Guadalcázar e o de Armadillo), existiram três etapas quanto aos sistemas de arrecadação. Assim, entre 1700 e 1723 se contemplou o

\footnotetext{
${ }^{44}$ Durán Sandoval (2007). A redução no número de "dezmatorios” entre 1765 e 1800 obedece a duas razões. Em primeiro lugar, à perda de territórios para outras dioceses: em 1777, o partido decimal setentrional do Rio Verde passou a formar parte do recém-criado bispado de Linares, e em 179512 freguesias da zona fronteiriça do bispado de Guadalajara (comarcas da Barca, Zapotlán el Grande e Colima) passaram a este bispado. Mazín (1996). Em segundo lugar, a um processo de agrupamento de "dezmatorios" com vistas a fazer mais eficiente a arrecadação. Por exemplo, a partir de 1775, o partido decimal do Armadillo se integrou ao de San Luis Potosí.
} 
arrendamento, o qual derivou num movimento pouco favorável para o cabido, já que com os seis contratos firmados nesse período o rendimento para a diocese passou de 5.995 pesos em 1700 a 6.000 pesos em 1723. Ou seja, um incremento insignificante. Numa segunda etapa, entre 1724 e 1775, a arrecadação experimentou um verdadeiro descolamento. A diferença entre 1723 (6.000 pesos) e 1724 (11.960 pesos), perto de $100 \%$, é mais que evidente. Foi o reflexo direto da mudança no sistema de arrecadação. Assim, enquanto entre 1700 e 1723 a renda decimal unicamente manifesta a capacidade de negociação entre o cabido e os arrendatários, entre 1724 e 1775, registra de maneira bastante fiel as variações na produção, na medida em que, como mostrou Lidya Espinosa, entre 1665 e 1786 não se registrou um aumento tendencial de preços no bispado de Michoacán. ${ }^{45}$

A terceira etapa, 1776-1800, implicou, seguindo a mudança de tendência no bispado, o retorno ao sistema de arrendamento (junto com a redução e fusão de diversos "partidos" decimais). Diante do ocorrido nas primeiras décadas do século XVIII, a mudança não acarretou um estancamento ou queda do rendimento. Ao contrário, se no quinquênio 1771-1775, último sob o sistema de administração, a média de arrecadação foi de 17.230 pesos, no de 1795-1799 alcançou os 25.150 pesos, isto é, um incremento de $46 \%$. A própria evolução da produção agropecuária no "dezmatorio", inflação incluída, mais o conhecimento adquirido sobre a realidade econômica do "dezmatorio", após mais de meio século de gestão direta, permitiram que o cabido negociasse em uma posição de força frente aos possíveis arrendatários do dízimo. No entanto, o custo para a historiografia é claro: a fonte deixa de registrar o movimento anual da produção e sua composição. Como destacamos, existe um consenso historiográfico em torno da afirmativa que a agricultura novo-hispana experimentou um processo de crescimento no século XVIII, de maneira que as diferenças se centralizam na periodização e intensidade desta expansão, uma expansão que, com diferenças regionais, produziu-se de maneira geral no vice-reino, como podemos observar nos dados de arrecadação decimal bruta e líquida de três dioceses importantes, por representarem alguns dos territórios mais povoados e de mais antiga colonização, a saber: Michoacán, Puebla e Oaxaca (ver Gráficos 2 e 3): ${ }^{46}$

\footnotetext{
${ }^{45}$ Espinosa (1995), p. 137.

${ }^{46}$ Não contamos com os dados do arcebispado do México porque não se conservam os livros de declarações de dízimos do século XVIII. O uso dos "nonos reais" para a reconstrução do dízimo líquido, considerando que este montante percebido pela Real Fazenda correspondia
} 


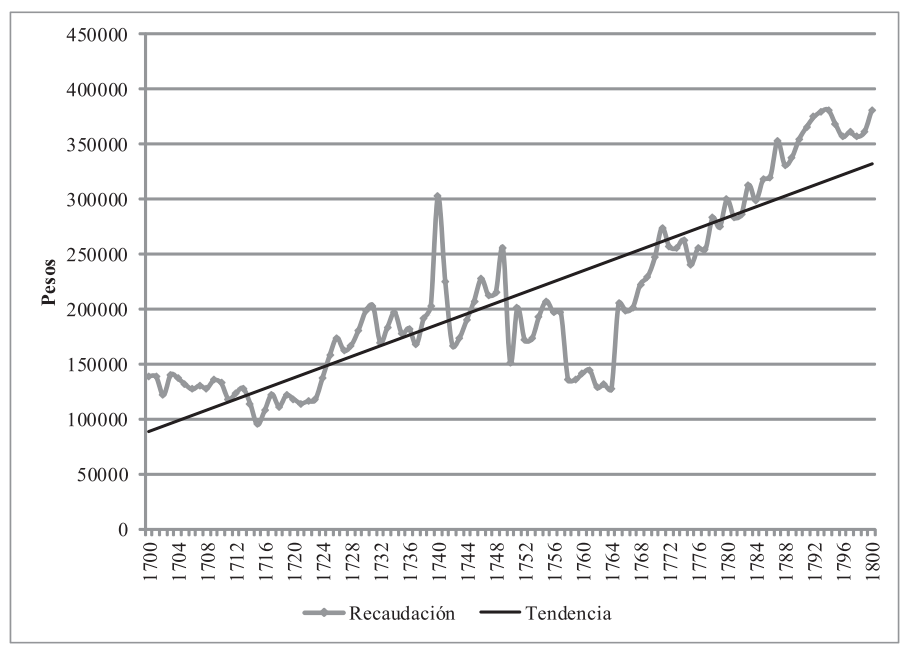

\section{Gráfico 2 - Dízimo bruto na diocese de Michoacán (1700-1800)}

Fonte: Sánchez Maldonado (1994), pp. 44-46 ${ }^{47}$

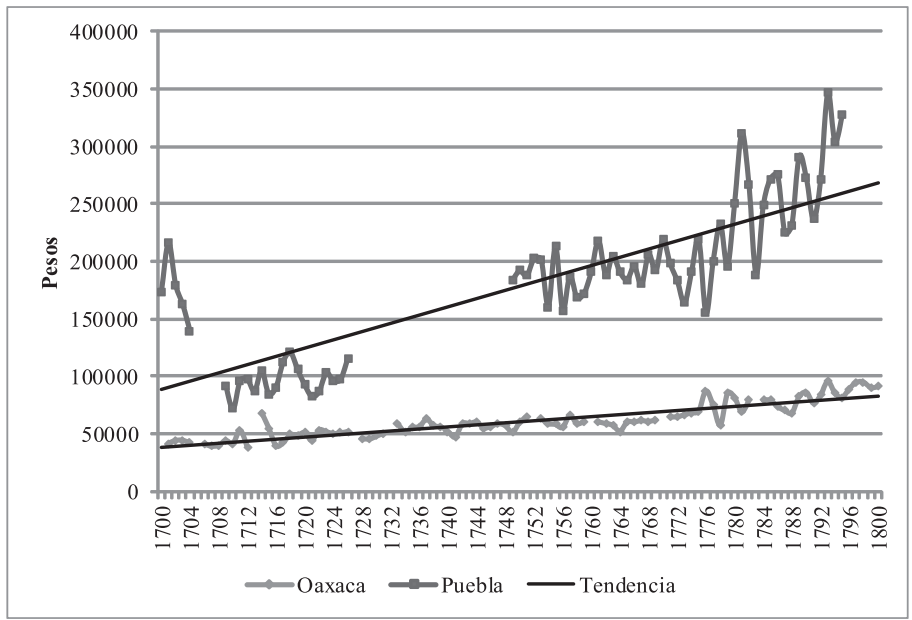

Gráfico 3 - Dízimo líquido nas dioceses de Puebla e Oaxaca (1700-1800)

Fonte: Oaxaca: Pasto et al. (1979), pp. 66-67; Puebla: Medina (1983), pp. 194 e 196.

a 11.1\% do dízimo líquido partível, não é possível, já que os dados consignados nas "cartascuentas" apresentam numerosos desvios, especialmente a alta, a partir da década de 1780, se se cotejam com outras fontes como os dados consignados na história da Real Fazenda que realizaram Fabián Fonseca e Carlos de Urrutia na década de 1790, por mandado do vice-rei segundo conde de Revillagigedo.

${ }^{47}$ Não utilizamos os dados de C. Morín porque são o resultado de um cálculo indireto, por meio de diversos múltiplos (por exemplo, sobre o valor da ordinária destinada à Inquisição), enquanto que os dados de Maria Isabel Sánchez Maldonado surgem de uma fonte homogênea: os quadrantes de dízimos da Igreja catedral de Michoacán. 
A agricultura dos três bispados experimentou um claro crescimento ao longo da centúria, ainda que com um ritmo desigual. Assim, a diocese que abarcava desde as zonas agrícolas dos vales de Valladolid de Michoacán e Pátzcuaro, passando pelas zonas mineiras de Guanajuato, San Luis Potosí e Guadalcázar, até as zonas semitropicais da Huasteca potosina, conheceu o crescimento mais notório, com uma taxa de crescimento anual de $1 \%$, seguida a distância pela diocese de Oaxaca $(0.7 \%)$ e Puebla $(0.6 \%)$ - ver Tabela 2.

Tabela 2 - Taxas de crescimento do dízimo nas dioceses de Michoacán, Oaxaca e Puebla (1700-1800)

\begin{tabular}{|l|c|c|c|}
\hline \multicolumn{1}{|c|}{ Diocese } & Dízimo & Taxa de crescimento & Período \\
\hline Michoacán & Bruto & $1 \%$ & $1700-1800$ \\
\hline Oaxaca & Líquido & $0.7 \%$ & $1701-1800$ \\
\hline Puebla & Líquido & $0.6 \%$ & $1700-1795$ \\
\hline
\end{tabular}

Fonte: Michoacán: Sánchez Maldonado (1994), pp. 44-46; Oaxaca: Pasto et al. (1979), pp. 66-67; Puebla: Medina (1983), pp. 194 e 196.

Um crescimento que mostrou notável paralelismo independentemente da diocese, se atentamos para os coeficientes de correlação entre elas. ${ }^{48}$ Onde se localizaria a causa deste crescimento?

É evidente que existe uma pluralidade de fatores que coadjuvaram a que a produção agropecuária novo-hispana crescesse durante o século XVIII. A primeira e fundamental, numa sociedade de antigo regime com escasso nível tecnológico, radica no crescimento demográfico. Tanto as análises "macro", realizadas a partir de recenseamentos e cálculos muito imperfeitos (censos de Fuenclara de 1743, de Bucareli de 1777, de Revillagigedo de 1791 e de Navarro Noriega de 1810), como os realizados a partir do estudo da demografia paroquial, constatam que a população do vice-reino cresceu durante a centúria, apesar de que a um ritmo mais acelerado durante sua primeira metade. ${ }^{49} \mathrm{O}$ impulso na demanda de produtos agropecuários gerado pelo incremento demográfico foi a razão de fundo do processo. Não obstante, a dinâmica agrícola recebeu um decidido arranque graças à expansão da produção de metais preciosos (ver Gráfico 4):

$48 \mathrm{O}$ coeficiente de correlação entre a série de Michoacán e Oaxaca foi de 0.8255 ; o de Michoacán com Puebla foi de 0.8191; o de Oaxaca com Puebla foi algo menor, ainda que significativo: 0.7723 .

${ }^{49}$ Alguns trabalhos que apresentam este fator, em: Rabell (1990) e (2001), Miño (2001), Sánchez Santiró (2003) e (2007). 


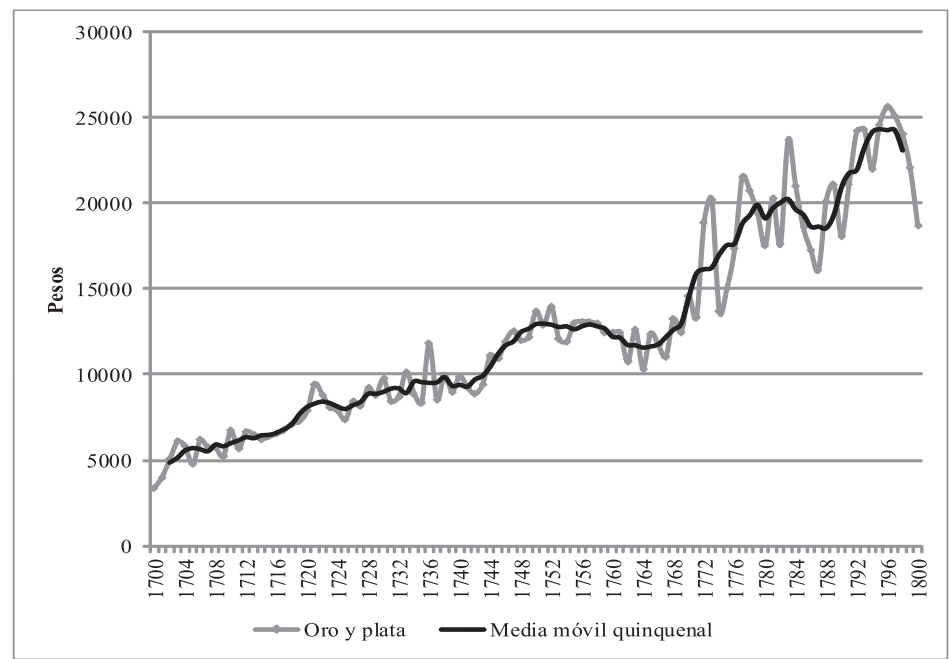

Gráfico 4 - Cunhagens da Casa da Moeda do México (1700-1800)

Fonte: LERDO DE TEJADA, Miguel. Comercio Exterior de México. Banco Nacional de Comercio Exterior, 1967, "Estado n 54".

Com uma taxa de crescimento anual durante o século XVIII da ordem de $1,7 \%$, a mineração novo-hispana constituiu-se num poderoso motor da economia em geral, e da agricultura, em particular; em especial, pelos encadeamentos "para trás" do setor minerador que levaram a uma forte demanda de produtos agropecuários, tanto para a alimentação da população trabalhadora e dos animais empregados nas minas (mulas, cavalos), no transporte de insumos e da produção, como nas fazendas que beneficiavam o mineral, além da demanda de sebo, couros, cordas, sacos, etc. O exemplo mais notório do impacto direto da mineração sobre a produção agropecuária é dado pela alta correlação existente entre a produção mineradora de metais preciosos de Guanajuato (que se converteria no principal núcleo minerador da Nova Espanha no século XVIII) e a evolução dos dízimos da diocese de Michoacán, que, segundo a análise de Cecilia Rabell, foi de 0,92 para o período $1715-1803 .{ }^{50}$

População e mineração são os fatores fundamentais que explicam o crescimento da agricultura novo-hispana no século XVIII, aos quais há de se juntar o impacto de uma urbanização crescente (tanto nas cidades e vilas, como nos núcleos mineradores e alguns portos, como

50 Rabell (1986), p. 62. 
Veracruz e Campeche), além do desenvolvimento de produções estratégicas para a Real Fazenda novo-hispana, como o tabaco nas vilas de Córdoba e Orizaba, destinadas ao estanco do tabaco, ou de produções agromanufatureiras como o açúcar, que além de atender à demanda do mercado interno, encontraram um nicho nos mercados internacionais, depois da crise de Santo Domingo em 1791.

\section{O Caso Brasileiro}

\subsection{Reconstrução do produto agrário do Brasil durante o século XVIII a partir da fonte decimal: historiografia e principais resultados}

A historiografia sobre o dízimo no Brasil não tem a mesma tradição que a existente para a Nova Espanha. Os primeiros trabalhos, das décadas de 1940 e 1950, fizeram uma rápida apresentação da natureza deste imposto. Manuel Cardoso chegou a apresentar cifras, mas somente para comprovar que a Coroa portuguesa destinava poucos recursos à Igreja, apesar de ser responsável pela arrecadação. ${ }^{51}$ Foi nos anos 1960 que os dízimos apareceram pela primeira vez como um indicador importante numa obra da historiografia econômica do Brasil: o livro de Frédéric Mauro sobre a economia atlântica portuguesa entre 1580 e 1640. Assim como para a Nova Espanha, o estudo de Mauro se inseria no marco das propostas da escola dos Annales. ${ }^{52}$ Contudo, diferentemente do que se passou com o México, os dízimos não se converteram em fonte fundamental para o estudo do desempenho da produção agropecuária brasileira. No entanto, o uso que Mauro fez dos dízimos tornou-se de fato um modelo. Nos anos de 1970 apareceram os trabalhos de Lyra e Maxwell sobre os dízimos, apesar de que apenas este último houvesse proposto uma análise sobre o desempenho da economia brasileira com base nos dados decimais, para enfatizar a situação da agricultura da capitania de Minas Gerais durante a segunda metade do século XVIII. ${ }^{53}$

Em que pese as importantes conclusões, mesmo que gerais, apresentadas por Maxwell, dever-se-ia esperar duas décadas até que esta fonte se convertesse num indicador importante para a historiografia

${ }^{51}$ Oliveira (1940) e Cardoso (1952).

52 Mauro (1960), pp. 219-225.

53 Lyra (1970) e Maxwell (1973). 
econômica do Brasil. Uma possível explicação para isto talvez seja o fato de que a partir dos fins dos anos 1970, a historiografia econômica no Brasil se viu fortemente influenciada por certos temas-chave que ganharam a atenção: o escravismo ou as relações comerciais entre a colônia e a metrópole, por exemplo. Outrossim, produziu-se um deslocamento no tipo de fontes: os documentos cartoriais passaram a ocupar o lugar que antes era reservado às fontes fiscais. E apesar de que Herbert S. Klein tenha tido e siga exercendo uma forte influência nos estudos de história econômica sobre o Brasil, não contávamos com investigações como as que realizou com John J. TePaske sobre as contas correntes da Real Fazenda.

Nos anos 1980, Stuart Schwartz reconheceu que, "embora o dízimo não seja uma medida substitutiva da produção, é uma indicação do valor provável desta última, baseado na melhor estimativa de um observador interessado e, como tal, é um índice razoavelmente bom da situação econômica". Como Mauro, reuniu os dados referentes ao mesmo período para discutir a conjuntura da produção açucareira no nordeste brasileiro, em especial o impacto da crise aberta com o fim da trégua com os holandeses, em 1621. E mais recentemente, Antônio Carlos Jucá de Sampaio apresentou e discutiu os valores dos contratos de arrendamento dos dízimos com o mesmo objetivo: inferir a evolução da agricultura do Rio de Janeiro entre 1652 e $1751 .^{54}$

Esta utilização restrita dos dados decimais talvez se explique, por um lado, pela qualidade das fontes para essas capitanias, que unicamente informam os valores dos contratos de arrendamento, sem maiores detalhes sobre as produções regionais; e, por outro lado, porque existem dados mais precisos correspondentes à exportação de açúcar (1698-1766) e tabaco (1666-1830) na documentação da Junta da Administração do Tabaco.

Nos fins dos anos 1990, e seguindo a tradição dos historiadores econômicos franceses, como Labrousse, Ladurie, Goubert e Meuvret, a tese de doutorado de Angelo Carrara destacou esta fonte para Minas Gerais. O autor fez um amplo levantamento das bases decimais disponíveis entre 1750 e 1835 e cartografou a produção agrícola dessa capitania.

${ }^{54}$ Schwartz (1988), pp. 154-157; Sampaio (2003), pp. 110-114.

Est. Econ., São Paulo, vol. 43, n.1, p.167-202, jan.-mar. 2013 
Dada a natureza fundamental da atividade agrícola que era flagrada pelos dízimos do Brasil - a produção de açúcar para a exportação - a arrecadação deste imposto recaía sobre os gêneros destinados à venda. E aqui nota-se uma semelhança com o observado no México. Apesar de que a arrecadação incidisse quase exclusivamente sobre os rendimentos da produção de açúcar, a decisão sobre qual gênero taxar dependia de seu nível de participação no comércio regional. Assim, a expansão da pecuária no interior permitiu a incorporação da arrecadação dos dízimos do gado. Do mesmo modo, com o crescimento da agricultura de abastecimento dos principais centros urbanos, tais como Salvador, Recife e Rio de Janeiro, iniciou-se a arrecadação das "miunças", isto é, os dízimos miúdos, que incidiam sobre gêneros hortifrutigranjeiros, frangos, galinhas, cabras e porcos. $\mathrm{Na}$ capitania de Ilhéus, no sul da Bahia, o gênero principal, objeto dos dízimos, foi a farinha de mandioca, produzida para satisfazer as demandas do mercado de Salvador. Desde 1670 também se impôs uma décima parte sobre o sal nas capitanias "onde há sal de mar o em terra." Não obstante, o conhecimento dos gêneros sobre os quais se centrava a arrecadação derivava de outras fontes, e não dos próprios registros decimais. Quanto a Minas Gerais, onde os dízimos corresponderam principalmente à produção de gêneros para $\mathrm{o}$ abastecimento interno, como milho, feijão e carne, a característica do sistema de arrecadação permite estabelecer uma aproximação à produção total, desde que se conheçam os níveis de preços dos gêneros sobre os quais incidia este imposto.

Tomemos o exemplo seguinte, a partir dos dados de Stuart Schwartz. No século XVII o açúcar participou com cerca do $90 \%$ no total dos dízimos, dos quais $66 \%$ pertencia ao açúcar branco. Por seu turno, em 1677 a arroba de açúcar branco custava 1.206 réis (equivalentes a dois pesos prata de oito reais), ao passo que o valor do contrato dos dízimos em 1677-1678 foi de 44.000000 réis (ou 73.350 pesos). Se os açúcares representaram em torno de $90 \%$ desse valor, então o total arrecadado com açúcares foi 39.600.000 réis (ou 60.000 pesos). Como o dízimo se refere à décima parte da produção agrícola, a produção total de açúcar declarada seria da ordem de 396.000 .000 réis (600.000 pesos). Sendo o açúcar branco, em média, $66 \%$ desse total, tem-se que o valor da produção de açúcar branco seria de 261.360 .000 réis (435.600 pesos). Assim, para conhecer o volume da produção total deste produto naquele ano basta dividir esta cifra pelo preço médio da arroba (1.206 réis), 
de forma que a produção de açúcar branco em 1677 seria próxima das 216.716,4 arrobas.

Porém, deve-se enfatizar que a natureza da informação disponível para os séculos XVII e XVIII em todas as capitanias do Brasil, com exceção de Minas Gerais, só permite considerar os dízimos em estudos sobre a tendência geral da produção agrícola e pecuária, já que não há mecanismos seguros para medir o nível de subregistro dos contratos, ou seja, a porcentagem da produção que não estava sujeita à tributação. Inclusive no que se refere a esta tendência talvez fosse mais apropriado considerar os dados a partir de médias móveis de, ao menos, três anos, o que compensaria boas colheitas com as medíocres.

Para os fins do século XVII, outro gênero deve ser incluído no valor dos contratos: o tabaco. De 1724 a 1726 a relação entre este produto e o açúcar ficou em torno de um quinto. Aqui sucede o mesmo que com o açúcar, isto é, não é adequado buscar estabelecer a produção total a partir dos dízimos. Um exemplo: o contrato dos dízimos na Bahia, no triênio de 1724 a 1727 esteve arrematado a uma média anual de 74 contos de réis (92.500 pesos). Aplicada a fórmula para o cálculo anterior ( $80 \%$ do total da produção em açúcar $20 \%$ em tabaco), a produção total de açúcar exportado seria de cerca de 592 contos de réis ( 740.000 pesos), e o tabaco, 148 contos de réis (185.000 pesos). Os dados de exportação, contudo, diferem marcadamente para o açúcar (862,7 contos de réis, ou 1.078.375 pesos), e menos para o tabaco (158 contos de réis, ou 197.500 pesos). A disparidade entre os valores não permite tanto pensar na possibilidade de subregistro, já que o que se ganha num ano se podia perder noutro, como em casos de má colheita, o que poderia inclusive determinar a falência do contratador. ${ }^{55}$

É na informação disponível para Minas Gerais que as fontes decimais se mostram mais promissoras, permitindo inclusive acompanhar o processo de ocupação e uso da terra, em particular, desde 1750 , quando a mineração começou a perder a força que tivera no meio século anterior. Em seguida, serão apresentados alguns exemplos sobre o comportamento do agro brasileiro durante os séculos XVII e XVIII.

$\overline{55}$ Carrara (2009b), pp. 78-80; Schwartz (1988), p. 403; Nardi (1996) p. 339. 
2.2. Algumas estimativas sobre o produto agrário brasileiro, séculos XVII e XVIII: Minas Gerais, Bahia, Pernambuco e Rio de Janeiro

Ao longo do século XVII as capitanias da Bahia e Pernambuco foram responsáveis por praticamente a totalidade da produção açucareira. Em 1623, uma profunda depressão ocorreu no setor devido ao fim da trégua com a Holanda, cuja recuperação só começou a tomar forma depois de dez anos. Durante a ocupação holandesa (1630-1654), a produção de açúcar no Rio de Janeiro adquiriu certa importância, mas no período seguinte Pernambuco tendeu a retomar sua posição destacada. Outra crise se produziu em 1686, e durou cerca de uma década, ao menos na capitania de Bahia, como se pode observar no Gráfico 5.

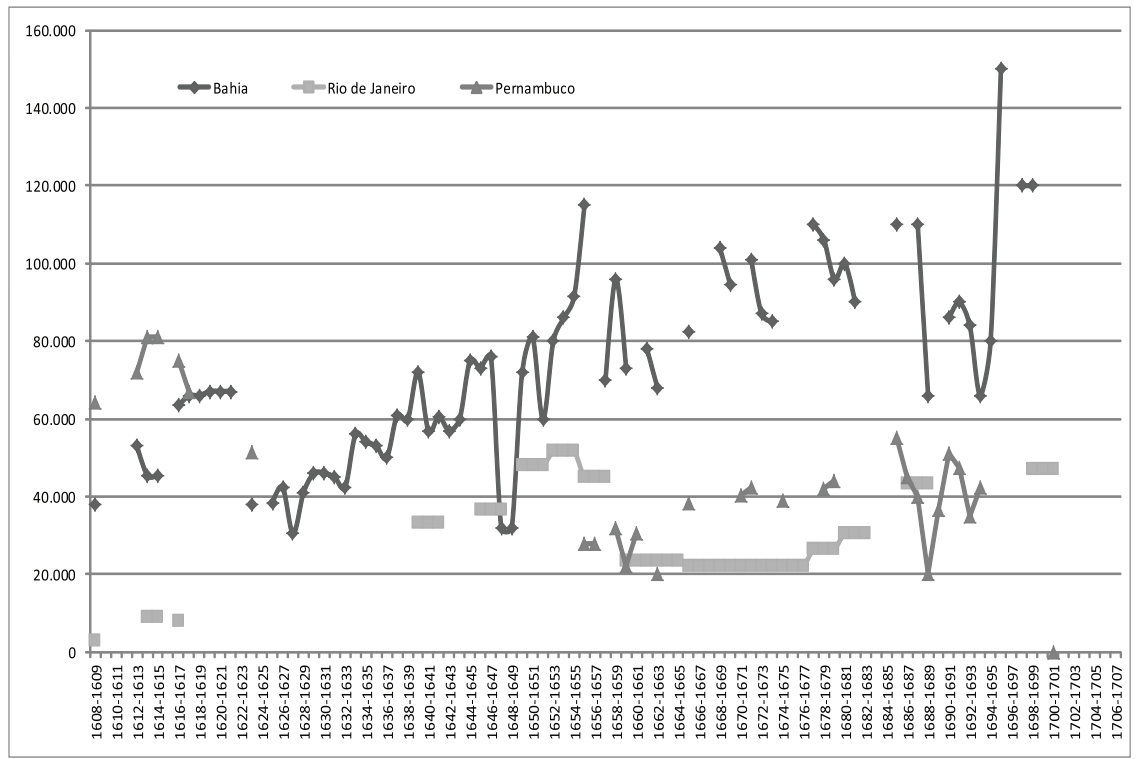

Gráfico 5 - Valor do contrato dos dízimos das capitanias da Bahia, Pernambuco e Rio de Janeiro, em milhares de cruzados - 1608-1706

Fonte: Carrara (2009a), pp. 125-127.

Frente à estagnação da arrecadação nos dízimos no Rio de Janeiro e à tendência de baixa dos de Pernambuco, Bahia aparece como uma região que experimentou um forte avanço durante o século XVII, o que poderia estar refletindo um crescimento agropecuário. Contudo, note-se que estamos lidando com os valores nominais dos contratos, 
já que a centúria esconde várias desvalorizações monetárias, especialmente entre 1641 e 1688. Isto nos obriga a considerar o valor real do contrato/produção (em marcos de ouro ou pesos prata, por exemplo). ${ }^{56}$ Ao fazer isto, o valor monetário dos arrendamentos adquire outro perfil. Tomemos o caso mais rico quanto à documentação e contrastante quanto aos resultados: os dízimos da capitania da Bahia (Gráfico 6).

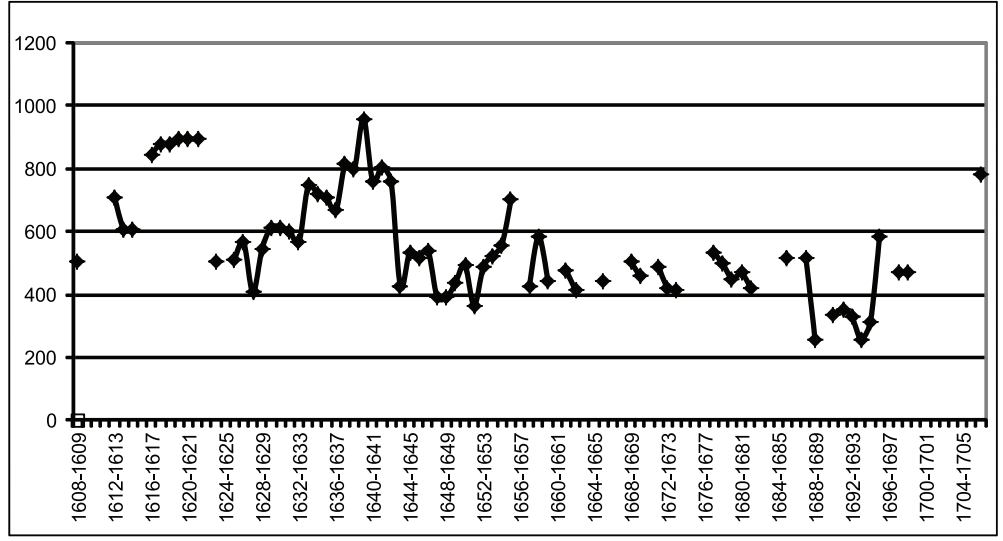

Gráfico 6 - Valor do contrato dos dízimos da capitania da Bahia em marcos de ouro, 1608-1706

Fonte: Carrara (2009a).

A tendência, por meio da conversão em marcos de ouro, é justamente a oposta à que nos dava o dízimo em réis: o século XVII presenciou uma tendência de queda do valor dos dízimos arrendados na capitania da Bahia. De fato, o melhor ano fiscal, depois da baixa dos anos 1620, passa a ser 1639-1640, enquanto que no Gráfico 6 era o biênio 1706-1707. Dito de outra maneira: o que os colonos ganhavam com a exportação de açúcar a partir de 1643 manteve-se estável e inclusive foi inferior ao obtido na década de 1620 . O curto período que vai de 1652 a 1656 representou uma alta excepcional, cujas razões se encontram na recuperação da capitania de Pernambuco por parte da Coroa portuguesa.

${ }^{56}$ No caso da Nova Espanha, uma operação como esta (conversão de réis em marcos de prata) é desnecessária, já que a moeda novo-hispana era mercadoria-dinheiro: o peso prata de oito reais. 
O século XVIII abre-se então com a descoberta de ouro em Minas Gerais e uma nova conjuntura financeira. A mineração aurífera brasileira de finais do século XVII e grande parte da primeira metade do século XVIII impactou de maneira rápida dois sectores: o comércio e a agricultura de abastecimento dos mercados locais. Assim, a capitania de Minas Gerais gerou não só ouro desde seu nascimento, mas também uma produção agrícola e pastoril responsável por aumento considerável dos rendimentos da Real Fazenda. Em contrapartida, a produção agrícola, medida pelo valor dos contratos dos dízimos em Pernambuco, Bahia e Rio de Janeiro (fortemente dominados pela produção de açúcar) não mostraram mudanças notáveis até o último quarto do século XVIII, pois que o estímulo se achava principalmente na demanda externa. Em Pernambuco, por exemplo, o valor do contrato dos dízimos de 1707 se repetiu ou decaiu pelo menos até a década de 1760 . O mesmo padrão de altos e baixos pronunciados que se encontra na segunda metade do século XVII parece explicarse pela mescla de colheitas abundantes e menores, ainda que com um padrão dominante de descenso na arrecadação que acompanhava bastante bem a queda tendencial que experimentou o preço do açúcar nos mercados americanos durante grande parte do século XVIII (Gráfico 7).

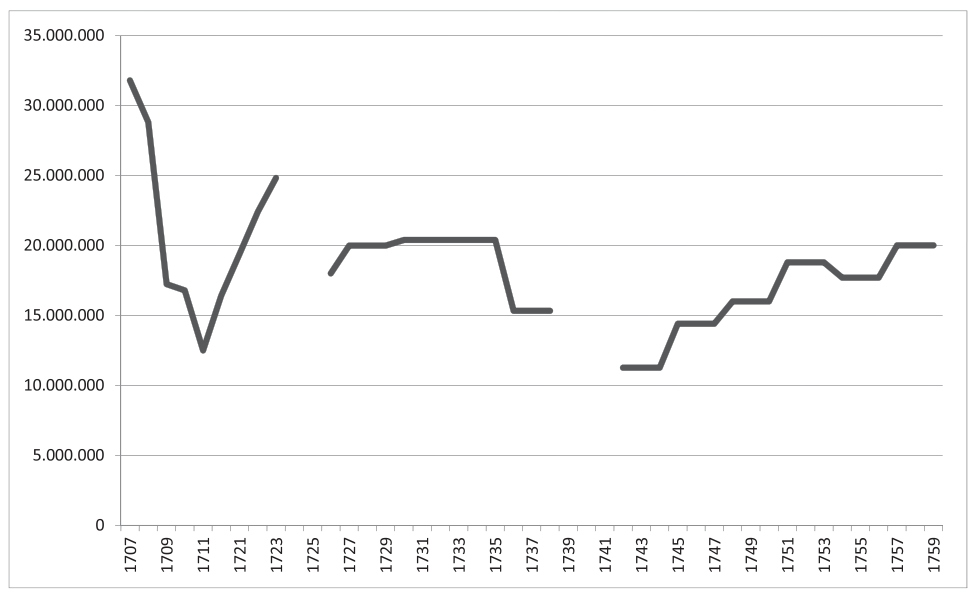

Gráfico 7 - Dízimos de Pernambuco, 1707-1759, em réis

Fonte: Carrara (2009b) pp. 239-253. 
Em Minas Gerais, pelo contrário, tanto a agricultura e a pecuária, que tinham como objetivo abastecer as regiões mineradoras, continuaram o caminho ascendente da produção de ouro até a década de 1760. Porém, a diminuição da produção aurífera teve o mesmo efeito sobre a agricultura e a pecuária. De fato, a diminuição da produção mineradora parece no início acompanhar a produção agrícola. Não obstante, este padrão que combina "dízimo agrícola-mineração de metais precisos" não se manteve a partir da década de 1770. Após uma breve estagnação iniciou-se um movimento ascendente, ainda que de menor intensidade, com relação àquele vivido na primeira metade do século XVIII (cf. Gráfico 8).

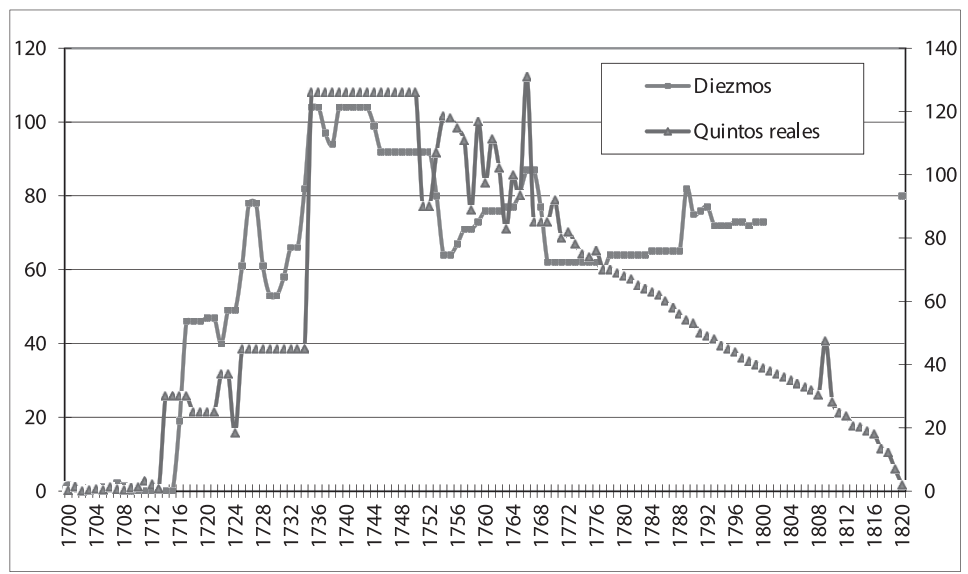

Gráfico 8 - Dízimos e quintos da capitania de Minas Gerais, 1700-1819, em contos de réis

Fontes: Maxwell (1977), "anexo estatístico”; Eschwege (1922), cap. 4; Matos (1981), parte 3, caps. 26/28/29.

Como explicar esta defasagem entre a mineração e a agricultura? Desde a década de 1770 a agricultura experimentou um movimento ascendente no Brasil, explicado pela forte demanda externa de gêneros tradicionais (açúcar, tabaco) e novos, como o algodão ou o café. Este movimento na capitania de Minas Gerais, porém, só impactou as zonas direta ou indiretamente articuladas aos mercados estrangeiros. Assim, no nordeste de Minas Gerais, onde se desenvolveu o cultivo do algodão, e na parte sul, registrou-se um forte crescimento da demanda agrícola e pastoril com origem no Rio de Janeiro. Mas foi 
no vale do rio Paraíba do Sul (nos atuais estados do Rio de Janeiro, São Paulo e Minas Gerais) que se estendeu o cultivo do produto que se converteria na força dominante ao longo do século XIX: o café.

Uma análise mais detida dos agentes econômicos que geravam a produção agropecuária de Minas Gerais permite mostrar que, do mesmo modo que sucedia com a produção mineral, a produção rural destinada ao mercado se concentrava em poucas mãos. Os maiores contribuintes eram aqueles que produziam os gêneros destinados à oferta interna. No entanto, entre 1750 e 1807 há outro movimento claramente visível: em geral, o nível de concentração parece haver diminuído significativamente.

De um lado, as unidades de produção escravistas experimentaram dificuldades tanto para manter o mesmo número de escravos, em decorrência dos problemas para sustentar o nível de substituição com escravos novos, como também para satisfazer os níveis de consumo da população das vilas e arraiais. Neste sentido, os registros dos dízimos mostram que o número de agricultores que produziam para o abastecimento interno na segunda metade do século XVIII subiu, isto é, se incorporaram novos participantes no contexto da crise mineradora. Por outro lado, nas freguesias das zonas fronteiriças da capitania de Minas Gerais o movimento é muito diferente. Em alguns casos, conheceram um forte crescimento da agricultura, e em outros, a produção parece estagnar-se.

Estes dados permitem conotar que a estabilização dos valores do dízimo deve ser lida como uma tendência de longo prazo à estagnação ou diminuição da produção escravista, e como um aumento nas zonas fronteiriças das pequenas unidades agrícolas. Assim, a situação no sul de Minas Gerais é bastante peculiar: o crescimento de sua agricultura e pecuária de exportação não está vinculado à crise da mineração. Em primeiro lugar, porque a mineração não havia sido importante ali e, em segundo lugar, porque seu mercado não se articulava com a região das minas, mas com o Rio de Janeiro. De fato, os primeiros sinais de expansão de sua produção agrícola datam da primeira metade do século XVIII, portanto, muito antes da citada crise. Estes movimentos sugerem a articulação de dois modos de produção em Minas Gerais: um, escravista, e outro, camponês. O primeiro abarcava, além da mineração, a agricultura e pecuária de abastecimento das zonas urbanas, ao passo que o segundo, uma agricultura e pecuária

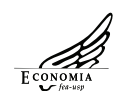


de pequenos produtores, cada vez mais numerosos. Com a crise do setor minerador, os grandes proprietários escravistas reduziram seus níveis de produção mercantil ou emigraram para outras regiões onde começaram a buscar outros cultivos mercantis, como nos casos do algodão ou o café.

Por último, devemos destacar o impacto da mineração no movimento demográfico. O século XVII se caracterizou por um crescimento demográfico muito limitado pelas guerras e pela natureza da atividade econômica dominante (a produção escravista de gêneros de exportação, que exigia grandes investimentos). No século XVIII, por sua vez, o ouro atraiu um grande contingente de pessoas, o que produziu em Portugal uma redução significativa de sua população. Nas últimas décadas do século XVIII, tanto o crescimento demográfico dos anos anteriores, como o aumento da demanda estrangeira de gêneros de exportação apoiaram o avanço da agricultura e da pecuária. ${ }^{57}$

\section{Considerações Finais}

A historiografia sobre o dízimo na Nova Espanha e Brasil mostra notáveis diferenças e particularidades quanto ao uso dado a esta fonte para a reconstrução da agricultura durante a época colonial. À gestão majoritariamente eclesiástica na Nova Espanha contrapõese a presença da Coroa portuguesa como instituição encarregada da arrecadação do imposto decimal, a que se deve acrescentar a primazia do sistema de arrendamento no Brasil em comparação com o de administração direta na Nova Espanha.

Diferenças que não podem subtrair-se à desigual relação de fatores e às atividades econômicas que dariam sustentação às nascentes estruturas fiscais no espaço colonial ibero-americano: a mineração de metais preciosos no caso novo-hispano e a produção açucareira (com seus derivados) no caso brasileiro, que só se reduziria com o desenvolvimento da mineração aurífera em Minas Gerais nos fins do século XVII.

Uma questão resultante deste estudo sobre o dízimo agrícola em ambos os espaços coloniais: o valor econômico da produção. Enquanto

${ }^{57}$ Sobre isso cf. Carrara, 2007 e 2009 b. 
no caso da Nova Espanha não é perceptível um processo inflacionário até finais do século XVIII, de forma que o dízimo líquido em moeda reflete no longo prazo as tendências na produção agropecuária e em seu valor econômico real, no caso do Brasil a depreciação do real até 1688, medida por sua conversão em marcos de ouro ou pesos prata, leva a que crescentes rendimentos nominais na arrecadação decimal não correspondam a um crescimento real de seu valor econômico no longo prazo.

Os estudos existentes não permitem apresentar uma visão global sobre a evolução do produto agropecuário em ambos os territórios, apesar de que os diversos estudos regionais (Michoacán, Puebla, Oaxaca, Pernambuco, Bahia ou Minas Gerais) de fato sinalizam para uma crescente produção agropecuária destinada aos circuitos mercantis a partir dos finais do século XVII e ao longo do século XVIII, resguardadas as peculiaridades dos espaços regionais (existência de núcleos de produção mineral, presença de mercados urbanos, conexão com os mercados externos, etc.) são os elementos que permitem explicar o desigual comportamento da produção agropecuária em economias que distanciavam muito de possuir um mercado nacional.

De fato, há coincidências muito interessantes: a agricultura novo-hispana experimentou um processo de crescimento no século XVIII, o qual, com diferenças regionais, produziu-se de maneira geral em todo o vice-reino. A razão de fundo foi o incremento demográfico que impulsionou a demanda de produtos agropecuários. Por seu turno, a dinâmica agrícola recebeu um decidido impulso graças à expansão da mineração de metais preciosos.

O quadro brasileiro, porém, requer considerar as flutuações de diferentes espaços econômicos. Em Minas Gerais, por exemplo, as atividades agrícolas e pecuárias destinadas ao abastecimento das regiões mineradoras experimentaram crescimento enquanto crescia a produção mineral, até a década de 1760 . A diminuição da produção aurífera teve o mesmo efeito sobre a agricultura e a pecuária. Não obstante, este padrão que combina "dízimo agrícola-mineração de metais preciosos" não se manteve a partir da década de 1770 , já que após uma breve estagnação iniciou-se um movimento ascendente, ainda que de menor intensidade ao vivido na primeira metade do século XVIII. Exatamente desde a década de 1770 a agricultura experimentou um movimento ascendente no Brasil, explicado pela forte 
demanda externa de gêneros tradicionais (açúcar, tabaco) e novos, caso do algodão ou o café. Este movimento na capitania de Minas Gerais, contudo, só impactou as zonas direta ou indiretamente articuladas aos mercados estrangeiros.

Finalmente, este artigo deixa claros o interesse, a riqueza e a diversidade do trabalho realizado sobre as fontes decimais agrárias brasileiras e novo-hispanas, mas também as diferentes agendas de investigação desenvolvidas pela historiografia econômica latino-americana desde os anos 60 do século XX até os albores do século XXI.

\section{Referências}

AGUIRRE Montaño, Luis Alberto, "El diezmo, del régimen colonial al México independiente. Tránsito institucional de una fiscalidad", tesis de licenciatura en Economía, Universidad Autónoma Metropolitana-Azcapotzalco, 2009.

BORAH, Woodrow, "The Collection of Tithes in the Bishopric of Oaxaca during the Sixteenth Century", The Hispanic American Historical Review, Vol. 21, No. 3 (Agosto), 1941, pp. 386-409.

, "Tithe Collection in the Bishopric of Oaxaca, 1601-1867", The Hispanic American Historical Review, Vol. 29, No. 4 (Noviembre), 1949, pp. 498-517.

BRADING, David A., Haciendas and Ranchos in the Mexican Bajio. León 1700-1860, Cambridge University Press, Londres, 1978 [Grijalbo 1986]

BRAVO Rubio, Berenise y Marco Antonio Pérez, "Una iglesia en busca de su independencia: el clero secular del arzobispado de México 1803-1822”, México, tesis de licenciatura, ENEP-Acatlán, 2001.

CARDOSO, Manuel. "Tithes in Colonial Minas Gerais". The Catholic Historical Review, Washington: The Catholic University of America Press, vol. 38, pp. 175-182, jul. 1952.

CARRARA, Angelo Alves. Minas e currais; produção rural e mercado interno de Minas Gerais, 16741807. Juiz de Fora: Editora da UFJF, 2007.

CARRARA, Angelo Alves. Receitas e despesas da Real Fazenda no Brasil, século XVII. Juiz de Fora: Editora da UFJF, 2009a.

CARRARA, Angelo Alves, Receitas e despesas da Real Fazenda no Brasil; século XVIII: Minas Gerais, Bahia, Pernambuco, Juiz de Fora, Editora Universidade Federal Juiz de Fora, 2009b.

CERVANTES Bello, Francisco Javier, "Crisis agrícola y guerra de independencia en el entorno de Puebla. El caso de San Martín y sus cercanías, 1800-1820”, Estudios de Historia Novohispana, vol. 20, México, 1999, pp. 107-133.

CORVERA Poiré, Marcela, "De la bonanza al ocaso: las colecturías de Taxco y sus alrededores entre 1783 y 1840”, en Ana Carolina Ibarra (coord.), La independencia en el sur de México, México, Facultad de Filosofía y Letras- Instituto de Investigaciones Históricas-Dirección General de Asuntos del Personal Académico-UNAM, 2004, pp. 103-164.

COSTELOE, Michael, "The Administration, Collection and Distribution of Tithes in the Archbishopric of Mexico, 1800-1860”, en The Americas, 23 (1), 1966, pp. 3-27.

DURÁN Sandoval, Felipe, “Tierra y conflicto en San Luis Potosí: 1700-1767”, tesis de doctorado en Historia Moderna y Contemporánea, Instituto Mora, 2007.

ESCHWEGE, Wilhelm L. von. Pluto Brasiliensis. Belo Horizonte: Imprensa Oficial, 1922.

Est. Econ., São Paulo, vol. 43, n.1, p.167-202, jan.-mar. 2013 
ESPINOSA Morales, Lydia, “Análisis de precios de los productos diezmados. El Bajío Oriental, 16651786”, en Virginia García Acosta (coord.), Los precios de alimentos y manufacturas novohispanos, México, Comité Mexicano de Ciencias Históricas/CIESAS/IIH-UNAM/Instituto Mora, 1995, pp. 122-172.

FARRISS, Nancy, La corona y el clero en el México colonial 1579-1821. La crisis del privilegio eclesiástico, traducción de Margarita Bojalil, México, 1995.

FLORES García, Georgina et al., "Producción agropecuaria de la región de Toluca según los diezmos, 1800-1828”, en Carlos Herrejón Peredo (dir.), Cuadernos de Historia, núm. II, enero-junio, Toluca, UAEM, 1980

FLORESCANO, E. Precios del maíz y crisis agrícolas en México (1708-1810), México, El Colegio de México, 1969.

FLORESCANO, Enrique y Lydia Espinosa, Fuentes para el estudio de la agricultura colonial en la diócesis de Michoacán: series de diezmos 1636-1810, 2 vols., México, INAH, 1987-1989.

FONSECA, Fabián de y Carlos de Urrutia, Historia general de Real hacienda escrita por..., México, Impresa por Vicente G. Torres, vol. III, 1850

GALICIA, Silvia, Precios y producción en San Miguel el Grande, 1661-1803, México, Dirección de Estudios Históricos-INAH, 1975.

GARAVAGLIA, Juan Carlos y Juan Carlos Grosso, "La región de Puebla-Tlaxcala y la economía novohispana (1670-1821)", Historia Mexicana, vol. XXXV: 4, 1986, pp. 549-600.

GARCÍA ACOSTA, Virginia, Los precios del trigo en la historia colonial de México, México, CIESAS, 1988.

, "Comparación entre el movimiento de los precios del trigo y del maíz y el alza generalizada de precios a fines de la época colonial”, en Virginia García Acosta (coord.), Los precios de los alimentos y manufacturas novohispanos, México, Comité Mexicano de Ciencias Históricas/ CIESAS/ Instituto de Investigaciones Históricas, UNAM/Instituto Mora, 1995, pp.173-192.

GARNER, Richard, "Price Trends in Eighteenth-Century Mexico", The Hispanic American Historical Review, Vol. 65, No. 2 (Mayo), 1985, pp. 279-325.

, "Precios y salarios en México durante el siglo XVIII", en Lyman Johnson y Enrique Tandeter (comps.) Economías coloniales. Precios y salarios en América Latina, siglo XVIII, Buenos Aires, Fondo de Cultura Económica de Argentina, 1992, pp.81-118.

GARNER, Richard y Virginia García Acosta, "En torno al debate sobre la inflación en México durante el siglo XVIII" en Jorge Silva y Juan Carlos Grosso (comp.), Circuitos mercantiles y mercados en Latinoamérica siglos XVIII y XIX, México, Instituto Mora, 1995.

GUEDEA, Virginia, La insurgencia en el departamento del norte. Los llanos de Apan y la Sierra de Puebla 1810-1816, México, Instituto de Investigaciones Históricas-UNAM/Instituto Mora, 1996. (Serie Historia Novohispana, 57)

Hamnett, Brian R., "Dye Production, Food Supply, and the Laboring Population of Oaxaca, 1750-1820", The Hispanic American Historical Review, Vol. 51, No. 1 (Febrero), 1971, pp. 51-78.

HERAS, Alberto de las, "El regio patronato indiano y la planificación de la labor evangelizadora por Fernando el Católico", Congreso de Historia del Descubrimiento (1492-1556). Actas. Tomo IV, Madrid, Real Academia de la Historia/Confederación Española de Cajas de Ahorro, 1992, pp. 501-524.

HURTADO, Flor, Dolores Hidalgo. Estudio Económico, 1740-1790, México, INAH, 1974. , "Dolores Hidalgo en el siglo XVIII, una aproximación cuantitativa", en Historia mexicana, vol. XXVII, núm. 4 (abril-junio, 1978), pp. 507-541.

IBARRA González, Ana Carolina, El Cabildo Catedral de Antequera, Oaxaca y el movimiento insurgente, Zamora, El Colegio de Michoacán, 2000. 
JARAMILLO Magaña, Juvenal, Hacia una iglesia beligerante, Zamora, Michoacán, El Colegio de Michoacán, 1996.

LINDO Fuentes, Héctor, "La utilidad de los diezmos como fuente para la historia económica", Historia Mexicana, Vol. 30, No. 2 (Oct. - Dic.), 1980, pp. 273-289.

LYRA, M. L. V. Os dízimos reais na capitania de São Paulo. Contribuição à história tributária do Brasil colonial (1640-1750), São Paulo. Dissertação (mestrado) da Faculdade de Filosofia, Letras e Ciências Humanas da Universidade de São Paulo, 1970.

MATOS, José Raimundo da Cunha. Corografia histórica da Província de Minas Gerais. Belo Horizonte: Arquivo Público Mineiro, 1981.

MAURO, Frédéric. Portugal et l'Atlantique au XVIIe siècle (1570-1670); étude économique. Paris: SEVPEN, 1960.

MAXWELL, Kenneth. Conflicts and conspiracies: Brazil \& Portugal 1750-1808. Cambridge: Cambridge University Press, 1973.

MAXWELL, Kenneth R. A devassa da devassa. Rio de Janeiro: Paz e Terra, 1977.

MAZÍN, Oscar, Entre dos majestades. El obispo y la Iglesia del Gran Michoacán ante las reformas borbónicas, 1758-1772, Zamora, El Colegio de Michoacán, 1987. , El cabildo catedral de Valladolid de Michoacán, Zamora, El Colegio de Michoacán, 1996. (dir.), Archivo del Cabildo Catedral Metropolitano de México: inventario y guía de acceso, México, El Colegio de Michoacán/Condumex-Centro de Estudios de Historia de México, 1999, 2 vols.

MEDINA Rubio, Arístides, La iglesia y la producción agrícola en Puebla, 1540-1795, El Colegio de México, México, 1983.

Menegus, Margarita, "La agricultura mexicana en la transición del siglo XVIII al XIX”, en Vetas. Revista del El Colegio de San Luis, año II, núm. 6 (sep.-dic., 2000), pp. 11- 36.

MIÑO Grijalva, Manuel, El mundo novohispano. Población, ciudades y economía, siglos XVII y XVIII, México, FCE/El Colegio de México, 2001.

NARDI, Jean Baptiste. O fumo brasileiro no periodo colonial. São Paulo: Brasiliense, 1996.Oliveira, Oscar de. Os dízimos eclesiásticos do Brasil nos períodos da Colonia e do Império, Juiz de Fora, Lar Católico, 1940.

ORTEGA González, Carlos Alberto, "El ocaso de un impuesto. El diezmo en el arzobispado de México, 1810-1833" (Tesis de maestría en Historia moderna y contemporánea), México, Instituto Mora, 2010.

OUWENEEL, Arij y Catrien C. J. H. Bijleveld, "The Economic Cycle in Bourbon Central Mexico: A Critique of the Recaudacion del diezmo liquido en pesos" The Hispanic American Historical Review, Vol. 69, No. 3 (Aug., 1989), pp. 479-530.

PASTOR et al., Fluctuaciones económicas en Oaxaca durante el siglo XVIII, México, El Colegio de México, 1979.

PASTOR, Rodolfo, Campesinos y reformas: La mixteca, 1700-1856, México, Centro de Estudios Históricos-El Colegio de México, 1987.

PÉREZ Mendoza, Mari Carmen: “Diezmos de indios en la colecturía de Huejutla, 1838-1855” (Tesis de licenciatura en Historia), ENAH, 2003.

PÉREZ Puente, Leticia, "Dos periodos de conflicto en torno a la administración del diezmo en el arzobispado de México: 1654-1663 y 1664-1680”, en Estudios de Historia Novohispana, núm. 25, (2001), pp. 15-57.

, "Fray Payo Enríquez de Rivera y el fortalecimiento de la iglesia metropolitana de la ciudad de México, S. XVII", tesis de doctorado en Historia, Facultad de Filosofía y Letras-UNAM, 2001. 
, Tiempos de crisis, tiempos de consolidación. La catedral metropolitana de la ciudad de México, 1653-1680, México, Centro de Estudios sobre la Universidad-UNAM/El Colegio de Michoacán/ Plaza y Valdés Editores, 2005.

QUINTANAR Zarate, Iliana Marcela, "El mercado rural novohispano. El caso de los llanos de Apan (1777-1811)", tesis de maestría en Historia Moderna y Contemporánea, México, Instituto Mora, 2007.

RABELL Romero, Cecilia, "San Luis de la Paz. Estudio de economía y demografía históricas, 16451810” (Tesis de maestría), México, Escuela Nacional de Antropología e Historia, 1975.

, Los diezmos de San Luis de la Paz: economía en una región del Bajío en el siglo XVIII, México, Instituto de Investigaciones Sociales-UNAM, 1986.

, La población novohispana a la luz de los registros parroquiales (avances y perspectivas de investigación), México, UNAM, 1990.

, "Oaxaca en el siglo XVIII. Población, familia y economía” (Tesis de doctorado en Historia), CEH-El Colegio de México, 2001.

REHER, d. S., “Malthus de nuevo? Población y economía en México durante el siglo XVIII” en Historia Mexicana, Vol. XLI: 4, 1992, pp. 615-664

ROMANO, Ruggiero, Moneda, seudomonedas y circulación monetaria en las economías de México en las economías de México, México, FCE/El Colegio de México, 1998.

ROMERO Alaniz, Fermín, El diezmo del valle de Toluca, siglos XVI y XVIII, Tesis de licenciatura en Historia, México, UAEM, 1999.

, "Precios y producción de maíz, trigo y cebada en el diezmatorio de Otumba, 1810 a 1835", en Guadalupe Zamudio y Gloria Camacho (coord.), Estado de México: experiencias de investigación histórica, México, UAEM, 2005, pp. 121-150.

SAMPAIO, Antônio Carlos Jucá de. Na encruzilhada do império: hierarquias sociais e conjunturas econômicas no Rio de Janeiro (ca. 1650-ca. 1750). Rio de Janeiro: Arquivo Nacional, 2003.

SÁNCHEZ Maldonado, María Isabel, Diezmos y crédito eclesiástico. El diezmatorio de Acámbaro 1724-1771, Zamora, El Colegio de Michoacán, 1994.

SÁNCHEZ Santiró, Ernest, Azúcar y poder. Estructura socioeconómica de las alcaldias mayores de Cuernavaca y Cuautla de Amilpas, 1730-1821, México, Universidad Autónoma del Estado de Morelos/Praxis, 2001.

, "La minería novohispana a fines del periodo colonial. Una evaluación historiográfica", Estudios de Historia Novohispana, vol. 27, (julio-diciembre), México, 2002, pp. 123-164

, Padrón del Arzobispado de México, 1777, México, AGN-Secretaría de Gobernación, 2003.

"El legado económico del antiguo régimen colonial novohispano", en Rafael Dobado, Aurora Gómez Galvarriato y Graciela Márquez (comp.), México y España. ¿Historia económicas paralelas?, México, E1 Trimestre Económico-FCE, 2007, pp. 137-182.

, "El desempeño de la economía mexicana tras la independencia, 1810-1870: nuevas evidencias e interpretaciones", en Carlos Marichal y Enrique Llopis (Coords.), Latinoamérica y España, 1800-1850. Un crecimiento económico nada excepcional, Madrid, Instituto Mora/Editorial Marcial Pons, 2008, pp. 65-109.

SCHWALLER, John Frederick, Origins of Church Wealth in Mexico: Ecclesiastical Revenues and Church Finances, 1523-1600, Albuquerque, The University of New Mexico Press, 1985 [FCE, 1990].

SCHWARTZ, Stuart. Segredos internos: engenhos e escravos na sociedade colonial, 1550-1835. São Paulo: Companhia das Letras, 1988.

SERRANO Ortega, José Antonio, "El sistema fiscal insurgente. Nueva España, 1810-1815”, en Relaciones, núm. 115, vol. XXIX, (verano, 2008), pp. 49-83.

SILVA Riquer, Jorge, “Tendencias de los granos básicos del diezmo en los partidos de Zamora, Valladolid, Puruándiro, Maravatío y Zitácuaro, Michoacán: 1660-1803”, en Jorge Silva Riquer, Juan 
Carlos Grosso, Carmen Yuste (comp.), Circuitos mercantiles y mercados en Latinoamérica. Siglos XVIII-XIX, México, Instituto Mora/IIH-UNAM, 1995, pp. 179-231.

, "Producción agropecuaria y mercados regionales en Michoacán, siglo XVIII", tesis de doctorado en Historia, El Colegio de México, 1997.

, "Los registros decimales y su utilidad para la historia agraria colonial novohispana", en América Latina en la historia económica, núm. 10 (julio-diciembre), 1998, pp. 51-63.

, "El espacio, la administración y la aplicación de los impuestos del diezmo y alcabalas en Michoacán, siglo XVIII”, en Ernest Sánchez Santiró, Luis Jáuregui y Antonio Ibarra (coords.), Finanzas y política en el mundo Iberoamericano. Del Antiguo Régimen a las naciones independientes, 1754-1850, México, UNAM/Instituto Mora/Universidad Autónoma del Estado de Morelos, 2001, pp. 261-290.

STAPLES, Anne, La iglesia en la primera república federal mexicana (1824-1835), traducción de Andrés Lira, México, Secretaría de Educación Pública, 1976. (SepSetentas, 237)

TEDESCO, Élida María, "Fiscalidad eclesiástica y guerra: el diezmo novohispano entre las necesidades financieras borbónicas y las exigencias de los conflictos armados de la independencia (17901810)", en prensa.

TEPASKE, John J., La Real Hacienda de Nueva España: la Real Caja de México (1576-1816), México, INAH-SEP, 1976.

TRASLOSHEROS, Jorge, La reforma de la Iglesia del Antiguo Michoacán. La gestión episcopal de fray Marcos Ramírez de Prado 1640-1666, México, Universidad Michoacana de San Nicolás Hidalgo, 1995.

WATSON Marrón, Gustavo et. al, Guía de documentos del archivo histórico del arzobispado de México. Del primer imperio a la república liberal, 1821-1862, introducción de Brian Connaughton, México, Arquidiócesis Primada de México, 2004. 